\title{
A prospective cohort study of prodromal Alzheimer's disease: Prospective Imaging Study of Ageing: Genes, Brain and Behaviour (PISA)
}

\author{
Michelle K. Lupton ${ }^{\text {a, }}$, Gail A. Robinson ${ }^{\text {b,c }}$, Robert J. Adam ${ }^{\text {a,d,e,f }}$, Stephen Rose ${ }^{\mathrm{g}}$, \\ Gerard J. Byrne $^{\mathrm{e}, \mathrm{f}}$, Olivier Salvado ${ }^{g}$, Nancy A. Pachana ${ }^{\mathrm{b}}$, Osvaldo P. Almeida ${ }^{\mathrm{h}, \mathrm{i}}$, \\ Kerrie McAloney ${ }^{a}$, Scott D Gordon ${ }^{a}$, Parnesh Raniga ${ }^{g}$, Amir Fazlollahi ${ }^{g}$, Ying Xia ${ }^{g}$, \\ Amelia Ceslis ${ }^{\mathrm{b}}$, Saurabh Sonkusare ${ }^{\mathrm{a}}$, Qing Zhang ${ }^{\mathrm{g}}$, Mahnoosh Kholghi ${ }^{\mathrm{g}}$, Mohan Karunanithi ${ }^{\mathrm{g}}$, \\ Philip E Mosley ${ }^{\mathrm{a}, \mathrm{c}, \mathrm{k}}$, Jinglei $\mathrm{Lv}^{1}$, Léonie Borne ${ }^{\mathrm{j}}$, Jessica Adsett ${ }^{\mathrm{a}}$, Natalie Garden ${ }^{\mathrm{a}}$, \\ Jurgen Fripp $^{g}$, Nicholas G. Martin ${ }^{a}$, Christine C Guo ${ }^{a, 1}$, Michael Breakspear ${ }^{a, j, 1}$ \\ ${ }^{\text {a }}$ QIMR Berghofer Medical Research Institute, Brisbane, Australia \\ ${ }^{\mathrm{b}}$ School of Psychology, The University of Queensland, St. Lucia, Brisbane, Australia \\ ${ }^{c}$ Queensland Brain Institute, The University of Queensland, St. Lucia, Brisbane, Australia \\ ' Centre for Clinical Research (UQCCR), The University of Queensland, Brisbane, Australia \\ ${ }^{\mathrm{e}}$ Royal Brisbane and Women's Hospital Mental Health Services, University of Queensland, Brisbane, Australia \\ ${ }^{\mathrm{f}}$ Faculty of Medicine, University of Queensland, Brisbane, Australia \\ ${ }^{g}$ CSIRO Health and Biosecurity, Australian E-Health Research Centre, Brisbane, Australia \\ ${ }^{\text {h }}$ Medical School, University of Western Australia, Perth, Australia \\ ${ }^{\mathrm{i}}$ WA Centre for Health and Ageing of the University of Western Australia, Australia \\ ${ }^{\mathrm{j}}$ The University of Newcastle, Newcastle, Australia \\ ${ }^{\mathrm{k}}$ Neurosciences Queensland, Brisbane, Queensland, Australia \\ ${ }^{1}$ Sydney Imaging \& School of Biomedical Engineering, The University of Sydney, Sydney, Australia
}

\section{A R T I C L E I N F O}

\section{Keywords:}

Alzheimer's disease

Neuroimaging

Neuropsychology

Genetic risk prediction

Protocol

At risk cohort

\begin{abstract}
A B S T R A C T
This prospective cohort study, "Prospective Imaging Study of Ageing: Genes, Brain and Behaviour" (PISA) seeks to characterise the phenotype and natural history of healthy adult Australians at high future risk of Alzheimer's disease (AD). In particular, we are recruiting midlife and older Australians with high and low genetic risk of dementia to discover biological markers of early neuropathology, identify modifiable risk factors, and establish the very earliest phenotypic and neuronal signs of disease onset. PISA utilises genetic prediction to recruit and enrich a prospective cohort and follow them longitudinally. Online surveys and cognitive testing are used to characterise an Australia-wide sample currently totalling over 3800 participants. Participants from a defined atrisk cohort and positive controls (clinical cohort of patients with mild cognitive impairment or early AD) are invited for onsite visits for detailed functional, structural and molecular neuroimaging, lifestyle monitoring, detailed neurocognitive testing, plus blood sample donation. This paper describes recruitment of the PISA cohort, study methodology and baseline demographics.
\end{abstract}

\section{Introduction}

The neurodegenerative process underlying dementia due to Alzheimer's disease (AD) spans several decades (Morris, 2005). Though the symptomatic burden of dementia typically occurs late in life, it is preceded by a long preclinical phase, characterized by the pernicious accumulation of neuropathology in the brain (Chiti and Dobson, 2006; Villemagne et al., 2013). This preclinical process is believed to commence decades prior to the establishment of functional decline and macroscopic brain atrophy (Dubois et al., 2016). Subtle, largely undetected changes in mood, anxiety and behaviour may accompany this process. Current therapeutic trials have usually targeted those with

\footnotetext{
* Corresponding author.

E-mail address: Michelle.Lupton@qimrberghofer.edu.au (M.K. Lupton).

1 Joint senior authors.
} 
established $\mathrm{AD}$ and therefore, perhaps irreversible neurodegeneration. It is possible that earlier intervention with disease-modifying therapy may increase the chance of halting or averting neurodegenerative processes, and the ensuing burden upon the individual and society. This therapeutic window can only be identified with large-scale studies of those individuals at future risk of $\mathrm{AD}$, but who currently lack substantial incipient neuropathology. The focus, therefore, of much ongoing dementia research is to elucidate early pathological changes, and to identify markers capable of predicting disease progression.

High risk cohorts for $\mathrm{AD}$ have typically been identified using neuropsychological tests in older adults, often recruited from "memory clinics" and with cognitive performance threshold abnormal for their age (mild cognitive impairment, MCI) (Gauthier et al., 2006; Winblad et al., 2004). However, longitudinal studies of MCI cohorts are beset by several limitations. First, up to two thirds of people meeting criteria for MCI do not convert to AD within the typical time frame of a longitudinal study (Ganguli et al., 2004; Ravaglia et al., 2006). Second, those who do convert may already possess a considerable burden of AD pathology (Iturria-Medina et al., 2017). Furthermore, the cross-sectional MCI criteria fails to capture the temporal nature of cognitive decline, and lack precision because the estimated baseline performance of individuals varies greatly. Moreover, many people who do develop AD do not pass through, or present with the classic amnestic profile of MCI: Early disturbances in other domains, such as language, visuospatial and executive functions are common (Lam et al., 2013). Alternative strategies, which leverage the potential of genetics and neurobiology, are needed.

The $\varepsilon 4$ allele of Apolipoprotein E (APOE) is the strongest known genetic risk factor for the common, "sporadic" (also known as late onset) AD (Saunders et al., 1993; Strittmatter et al., 1993). Large scale GWAS meta-analyses have identified at least 24 additional AD genetic risk variants (Harold et al., 2009; Hollingworth et al., 2011;Kunkle et al., 2019; Lambert et al., 2009, 2013; Naj et al., 2011). While these common genetic variants individually account for a small variance of the disease risk, their combination, as estimated by a polygenic risk score (PRS), explains a substantial amount of the heritability. A high prediction accuracy ( $\sim 87 \%$ of the area under the receiver operation curve, AUC) can be achieved by a prediction model including APOE genotype and PRS (containing GWAS association SNPs with $p$ value $<0.5$ ). The PRS adds significant predictive value over APOE alone (Escott-Price et al., 2015). AD PRS, with the APOE region excluded (PRS-no APOE), is a robust predictor of age of $\mathrm{AD}$ onset, improving the ascertainment of age of $\mathrm{AD}$ onset among $A P O E \varepsilon 3 / 3$ individuals by $>10$ years between the lowest and highest risk deciles (Desikan et al., 2017). Work from our own group has shown that AD PRS-no APOE is associated with reduced hippocampal volume in healthy older adults and those with mild cognitive impairment (MCI) (Lupton et al., 2016). The APOE genotype and PRS-no $A P O E$ both hold an association with longitudinal cognitive decline, structural MRI measures (e.g. hippocampal complex cortical thickness), and radioisotope imaging or cerebrospinal fluid identified amyloid and total tau positivity (Harrison et al., 2016; Tan et al., 2017a, 2017b).

Polygenic risk prediction therefore offers a powerful avenue to identify individuals at high risk of AD. Onto this familial risk is added a host of potentially modifiable risk factors, including hearing loss (Loughrey et al., 2018), insomnia (Xu et al., 2020), cardiovascular (McGrath et al., 2017) and metabolic (Kivimaki et al., 2018) health, traumatic brain injury and lifestyle factors, such as diet (Opie et al., 2013), social isolation, sedentary behaviour (Sabia et al., 2017) and smoking [for review, see (Livingston et al., 2020)]. Studying healthy midlife and older adults at high genetic risk of future AD therefore offers a unique opportunity across a number of domains: to understand the neuropathological processes from their putative onset; the influence of modifiable risk factors on the evolution of these changes; the emergence of comorbid symptoms (such as low mood and anxiety); the variable onset of cognitive changes during conversion from high risk to $\mathrm{AD}$; and the relationship between molecular, structural and functional brain changes. To do so requires ascertainment of such a cohort and detailed phenotypic characterization at regular periods, using imaging, neurocognitive assessment, genetic and biochemical characterization, lifestyle and mental health factors.

Here, we use existing cohorts with available GWAS data to establish a longitudinal cohort with elevated risk for $\mathrm{AD}$ to study precursors and lifestyle risk factors for AD. Our Prospective Imaging Study of Ageing: Genes, Brain and Behaviour (PISA) comprises the following overarching objectives:

(1) Identify healthy middle-aged and older Australians at high risk of dementia;

(2) Discover biological markers and phenotypic characteristics of early neuropathology;

(3) Identify modifiable risk factors;

(4) Establish a cohort of preclinical patients for future clinical trials.

Several specific imaging innovations were developed for our study. First, we adapted several advanced HCP protocols for the PRISMA platform, using a combination of multiband, multi-echo and multishell dMRI, fMRI, sMRI and QSM sequences. Second, we did this in a manner that was optimized for a time-limited session suitable for older, clinical populations, breaking acquisitions into brief time blocks were possible. Third, we acquire simultaneous MRI and PET (amyloid) images, using the integrated mMR platform to acquire resting state EPI and ASL sequences that serve both as motion correction data for PET image and for resting state BOLD and ASL sequences in their own right.

\section{Material and methods}

\subsection{Study design}

PISA is a prospective cohort of healthy Australians at mid to late adulthood, who occupy the two tails of the genetic risk spectrum for lateonset AD. PISA participants derive from extensive in-house cohorts drawn from longitudinal studies of Australian twins and their families conducted over four decades with available genome wide genotyping data to enable a genetically enriched cohort (Fig. 1). The PISA study protocol has approval from the Human Research Ethics Committees (HREC) of QIMR Berghofer Medical Research Institute and the University of Queensland.

\subsection{PISA online}

\subsubsection{Online survey}

The sample recruitment pool $(\mathrm{N}=15,351)$ comprises adult twins, their spouses, and first-degree relatives of twins and spouses who, over previous decades have volunteered for studies on risk factors or biomarkers for physical or psychiatric conditions and have previously been genome-wide genotyped (Benyamin et al., 2009; Heath et al., 2011). Volunteers have previously given informed consent to be contacted to take part in additional studies. These previous studies span a period of up to 40 years. Postal, telephone or email re-contact of all research participants in the age range of 40-80 years old (dob: years 1946-1986), was undertaken in order to introduce the study and update contact details. Where contact was lost, we endeavoured to obtain participant's most recent residential address by accessing electoral roll information (available for public inspection at Australian Electoral Commission offices). Currently 9685 (63\%) participant records have been successfully updated with attempts at contact ongoing.

All participants who respond to this initial contact are invited to complete an online survey providing a global assessment of lifestyle, cognitive and behavioural function. A comprehensive online survey using Qualtrics Survey software (Qualtrics, Provo, UT, USA) allows participants to complete the survey from home (Table 1). Participants are invited by email with a link to the survey. The survey begins with an 


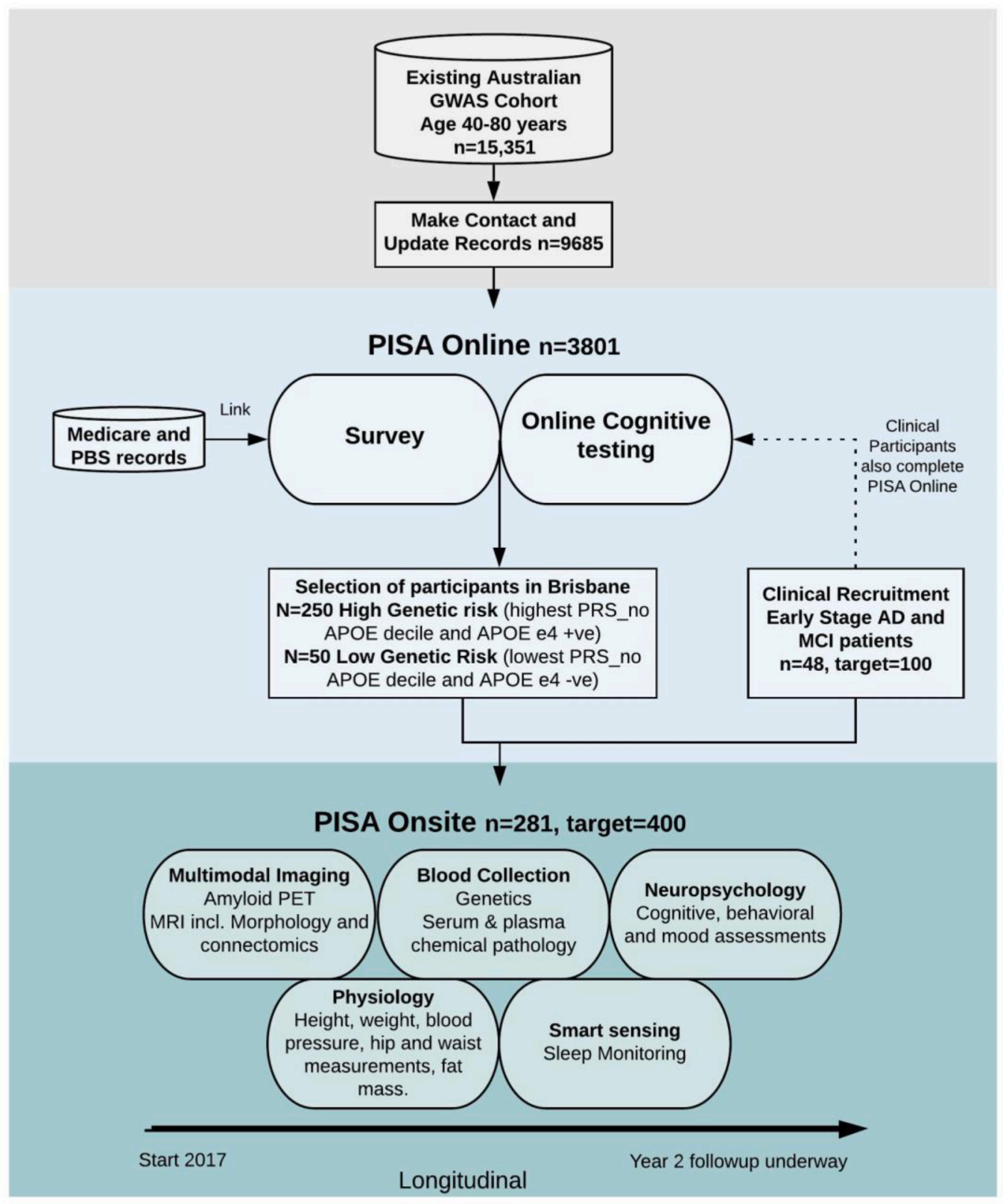

Fig. 1. Overview of the PISA study. Sample sizes are current as of 21/08/2020.

information and consent page followed by a core module that captures the central dataset (Table $1 \mathrm{~B}$ ). We also ask for permission to link participant data with MBS (Medicare Benefits Scheme) and PBS (Pharmaceutical Benefits Scheme) records. Australia has a universal health care system and this allows us to access all government subsidized medical care and prescriptions from the previous 4.5 years. Once the core module is complete, the remaining survey is made up of ten additional modules (Table $1 \mathrm{~A}$ ), which can be completed at any time in any order, with the typical time required for completion provided on the menu screen. The survey includes over 30 validated instruments (full details are listed in Appendix A). To foster collaboration, the questions were harmonized with data acquired in other national and international dementia and elderly cohorts (including the Older Australian Twin Study (OATS) (Sachdev et al., 2009), the Healthy Brain Aging (HBA) Clinic cohort eHealth survey (LaMonica et al., 2017), the Australian Imaging Biomarkers and Lifestyle (AIBL) study (Ellis et al., 2009), the European Medical Information Framework for AD (EMIF-AD) PreclinAD study (Konijnenberg et al., 2018) and the Brain Health Registry (Weiner et al., 2018). There is currently no time limit for the completion of the online survey and participation follow-up is currently ongoing. In addition, upon request or when email contact has not been established, paper copies of the core module and module 3 (medical history) are mailed to participants for completion. The participant can then complete the remaining modules online if they are able and wish to.

\subsubsection{Online cognitive testing}

All participants who complete the survey are invited to undertake online cognitive testing (Table 2). Participants are first invited to complete the online cognitive assessments via the Cambridge Brain Sciences (CBS) platform (Corbett et al., 2015) approximately two to three months after completion of the online survey. Participants are then approached to complete the Cogstate (Mielke et al., 2015) and Emotion Recognition (Kessels et al., 2014) tests. A second time point of online cognitive assessments is being carried out approximately one year after the baseline assessments. 
Table 1

Summary of PISA online survey.

\begin{tabular}{ll}
\hline A. PISA Online Survey Modules & Average time to complete (median m:s) \\
\hline 1. Core Module (see B. below) & $26: 00$ \\
2. Memory \& Cognition & $8: 31$ \\
3. Medical History & $12: 27$ \\
4. Personal Wellbeing & $12: 02$ \\
5. Lifestyle & $15: 17$ \\
6. Personality & $15: 24$ \\
7. Life Events & $15: 40$ \\
8. Feelings \& Emotions & $13: 00$ \\
9. Physical Health & $17: 04$ \\
10. Women's Health & $5: 50$ \\
11. Pain & $3: 37$ \\
\hline
\end{tabular}

B. PISA Online Survey Core Module Items

Key demographics

Education and occupation

Extended family

Biological family medical history

General memory and health questions

Alcohol/substance abuse \& smoking status

Patient Health Questionnaire (PHQ-9)

Generalised Anxiety Disorder (GAD-7)

Medications checklist

Active Australia Survey

Brief personal medical history (PISA exclusion criteria)

A. Names of each of the 11 modules and the time taken for completion.

B. Sections included in the core module.

Full details including instruments used and references are listed in Appendix A.

Table 2

PISA online cognitive assessment platforms.

\begin{tabular}{|c|c|c|c|}
\hline $\begin{array}{l}\text { Online } \\
\text { platform }\end{array}$ & Task details & $\begin{array}{l}\text { Approximate time to } \\
\text { complete (min) }\end{array}$ & Reference \\
\hline $\begin{array}{l}\text { Cambridge } \\
\text { Brain } \\
\text { Sciences } \\
\text { (CBS) }\end{array}$ & $\begin{array}{l}\text { Twelve subtests of } \\
\text { memory, reasoning, } \\
\text { concentration and } \\
\text { planning }\end{array}$ & 30 & $\begin{array}{l}\text { (Corbett } \\
\text { et al., } \\
2015 \text { ) }\end{array}$ \\
\hline Cogstate & $\begin{array}{l}\text { Online card games to test } \\
\text { processing speed, } \\
\text { attention (choice } \\
\text { reaction time paradigm), } \\
\text { visual memory (pattern } \\
\text { separation paradigm) } \\
\text { and working memory (n- } \\
\text { back paradigm) }\end{array}$ & $\begin{array}{l}30 \text { (including } 15 \text { for } \\
\text { practise session and } \\
15 \text { for baseline } \\
\text { session) }\end{array}$ & $\begin{array}{l}\text { (Mielke } \\
\text { et al., } \\
\text { 2015) }\end{array}$ \\
\hline $\begin{array}{l}\text { Emotion } \\
\text { Recognition }\end{array}$ & $\begin{array}{l}\text { Participants label } \\
\text { emotional facial } \\
\text { expressions presented as } \\
\text { morphs gradually } \\
\text { expressing one of the six } \\
\text { basic emotions }\end{array}$ & 15 & $\begin{array}{l}\text { (Kessels } \\
\text { et al., } \\
\text { 2014) }\end{array}$ \\
\hline
\end{tabular}

\subsubsection{Genetic risk prediction}

Genome-wide genotyping of participants within our recruitment pool was previously performed using a range of genotyping arrays including Illumina chips designed using HapMap references (317 K, 370 $\mathrm{K}, 610 \mathrm{~K}, 660 \mathrm{~K}$ ) and more recent Illumina arrays designed using the $1 \mathrm{KGP}$ reference (Core + Exome, PsychArray, OmniExpress) as previously detailed (Cuellar-Partida et al., 2015; Medland et al., 2009). All datasets have been combined with strict quality control procedures and imputed to the Haplotype Reference Consortium (HRC) Release 1 reference panel (McCarthy et al., 2016).

2.2.3.1. APOE genotyping. The three main APOE alleles- $\varepsilon 2, \varepsilon 3$ and $\varepsilon 4$ -differ at two residues (rs429358 and rs7412) and so consist of a two single-nucleotide polymorphism (SNP) haplotype. We have previously ascertained the reliability of imputed $A P O E$ genotypes within our inhouse dataset on each different genome-wide genotyping array used, using replication genotyping of 3576 samples (Lupton et al., 2018). If directly genotyped on the array or imputed with a genotype hard call imputation threshold of $\geq 0.9$, and concordance threshold of $>99.3 \%$ with our previous replication genotyping then we used the array based $A P O E$ genotype data. Samples not meeting these requirements were directly genotyped at the $A P O E$ locus using TaqMan SNP genotyping assays on an ABI Prism 7900HT and analyzed using SDS software (Applied Biosystems). SNPs were determined by allelic discrimination assays based on fluorogenic $5^{\prime}$ nuclease activity.

2.2.3.2. Polygenic risk score (PRS). PRS-no APOE was constructed from genome-wide SNP array data by summing the number of risk alleles weighted by the effect size (log odds ratio) as previously described (Lupton et al., 2017). Risk alleles were identified from the largest AD GWAS meta-analysis available at the start of the study, performed by the IGAP consortium (Lambert et al., 2013) (see Appendix C for details of the IGAP discovery sample). SNPs within $500 \mathrm{~kb}$ either side of the APOE locus were excluded to ensure all $A P O E$ associated signal was removed. A large number of SNPs associated with $\mathrm{AD}$ risk were included in the PRS, including variants associated at a level below genome-wide significance. A threshold of $p \leq 0.5$ was chosen for inclusion in the PRS, as this has previously been shown to have the greatest predictive value (Escott-Price et al., 2015). Linkage disequilibrium (LD)-based clumping was carried out, providing the most significantly associated SNP in each region of LD (pairwise $\mathrm{r}^{2}$ threshold of 0.2 and a physical distance threshold of $300 \mathrm{~kb}$ ).

\subsection{PISA onsite}

\subsubsection{PISA onsite overview}

A subset of the online participant sample is selected for recruitment into the onsite arm of the study (PISA onsite). These include eligible individuals (criteria listed below) who are designated at high $(\mathrm{N}=250)$ or low risk $(\mathrm{N}=50)$ of $\mathrm{AD}$ based entirely on genetic classification. Those in the low risk group are in the lowest quintile of the AD PRS-no APOE ( $A P O E$ gene region excluded) and are non $A P O E \varepsilon 4$ carriers. Those in the high risk group are either $A P O E \varepsilon 4$ carriers (including both homozygotes and heterozygotes), or those in the highest quintile of the PRS-no APOE. These groups, at either end of the $\mathrm{AD}$ genetic risk spectrum, were chosen to optimise the power to detect differences in biology and/or cognitive phenotype according to future $\mathrm{AD}$ risk. A detailed description of the genetic classification is given in the genetics section below.

In addition to the genetically enriched sample, 100 early stage or preclinical $\mathrm{AD}$ patients are being recruited from public and private memory clinics in Australia as comparative cases. These participants are recruited to provide a cohort of early $\mathrm{AD}$ changes against which to benchmark findings from (high-low) risk contrasts in our healthy cohort.

The process of physical, cognitive and neurobiological ageing will be closely monitored through the use of comprehensive examinations which cover five domains of investigation: multimodal imaging (PET and MRI), genetics, neuropsychology (cognition), smart sensing (lifestyle), and physiology. Participants will be followed up in a 2-3 year time window following for all baseline modalities, except for the PET scan. In brief, participants recruited into PISA onsite undergo thorough comprehensive examinations that quantify the structural and functional integrity of the brain, as well as the presence of neuropathology. Longitudinal neuropsychological, physiological and lifestyle data are also acquired. A bioinformatics database platform has been developed to capture all data, permitting multivariate and machine learning analyses to establish brain-behaviour, gene-brain, and gene-behavioural relationships and their mediation by $\mathrm{AD}$ genetic risk.

\subsubsection{Genetically enriched cohort participant selection}

Participants were approached for recruitment into PISA onsite once they had completed at least the core module on the online survey. If a 
participant lived within a feasible travelling distance (approximately $100 \mathrm{~km}$ ) of our testing site at QIMR Berghofer in Brisbane, they were sent information via email or mail about the PISA onsite study. This approach has yielded a $36 \%$ response rate. Once a participant expressed interest, they were screened for metal safety and eligibility, and if they met these criteria they were invited to make an appointment. Inclusion and exclusion criteria are shown in Box 1.

Box 1. Criteria for recruitment of Healthy research participants into PISA onsite Inclusion Criteria

- Recruited from existing GWAS studies at QIMR Berghofer according to their genetic risk profile (see main text). Participants previously provided a DNA sample for GWAS and gave consent to participate in other ethically approved studies.

- Aged 40-70 years

- Fluent in English

- Able to provide informed consent

Exclusion Criteria

- Any significant neurological disorder other than Alzheimer's disease (including stroke, vascular dementia, Parkinson's disease, Huntington's disease, normalpressure hydrocephalus, CNS tumour or infection, seizure disorder, multiple sclerosis, or history of significant head trauma followed by haematoma, persistent neurological deficits or known structural brain abnormalities).

- Any history of neurosurgery

- Any significant medical condition that may confound neuropsychological testing (including chronic renal failure, chronic hepatic disease, severe pulmonary disease).

- Current alcohol or substance (except tobacco) abuse or a past history of alcohol or substance (except tobacco) dependence.

- History of severe psychiatric illness or current psychiatric symptoms that may confound neuropsychological testing (including major depression with psychotic symptoms, bipolar disorder or schizophrenia).

- Females who are pregnant or breastfeeding.

- Presence of prostheses or other objects that post a risk for MRI) including pacemaker, aneurysm clips, artificial heart valves, cochlear implants, metal fragments or foreign objects in the eyes, skin or body).

\subsubsection{Clinical cohort participant selection}

The clinical cohort is recruited via local clinicians (neurologists, geriatricians, psychiatrists and general physicians) who see patients with cognitive concerns. Recruitment sites include the following health facilities in Brisbane: The Royal Brisbane and Women's Hospital, The Wesley Hospital, The Mater Hospital, and Neurosciences Queensland, a private practice. Referrals are made to the team of PISA clinicians who then assess the suitability of referred patients according to clinical, neuropsychological and imaging criteria. PISA aims to recruit patients in the early stages of Alzheimer's disease or whose clinical phenotype (aMCI) is suggestive of and highly likely to predict later diagnosis of Alzheimer's disease. To facilitate the discovery of relevant AD biomarkers, patients with significant comorbidities (including, but not limited to major psychiatric illness or cerebrovascular disease) are excluded. If the inclusion criteria (Box 2) are met, patients are discussed at a consensus meeting between PISA clinicians, before determining their suitability for enrolment. The consensus meeting involves a review of case notes, available clinician correspondence, CT, MR and metabolic imaging (including SPECT and FDG-PET but not amyloid PET), and neuropsychological test results, where available.

Box 2. Criteria for recruitment of Clinical research participants into PISA onsite Inclusion Criteria

- Meet DSM-5 Criteria for Mild Neurocognitive Disorder or Major Neurocognitive Disorder of the Alzheimer's Type or NIA-AA Criteria for Mild Cognitive Impairment or Dementia of the Alzheimer's type.

- Mini-mental state examination (MMSE) > 20 and a Clinical Dementia Rating (CDR) of 0.5 or 1.0 .

Exceptions to these criteria were made for clinically-probable cases of logopenic primary progressive aphasia (wherein language deficits might result in a lower MMSE) or posterior cortical atrophy (PCA) (wherein amnestic deficits may not be prominent).

- Age 40-80 years

- Fluent in English

(continued on next column) (continued)

- Able to provide informed consent

- Exclusion Criteria

- Any significant neurological disorder other than Alzheimer's disease (including stroke, vascular dementia, Parkinson's disease, Huntington's disease, normalpressure hydrocephalus, CNS tumour or infection, seizure disorder, multiple sclerosis, and history of significant head trauma followed by haematoma, persistent neurological deficits or known structural brain abnormalities.

- Any history of neurosurgery

- Any significant medical condition that may confound neuropsychological testing (including chronic renal failure, chronic hepatic disease, severe pulmonary disease).

- Current alcohol or substance (except tobacco) abuse or a past history of alcohol or substance (except tobacco) dependence.

- History of severe psychiatric illness or current psychiatric symptoms that may confound neuropsychological testing (including major depression with psychotic symptoms, bipolar disorder or schizophrenia).

- Females who are pregnant or breastfeeding.

- Presence of prostheses or other objects that post a risk for MRI)including pacemaker, aneurysm clips, artificial heart valves, cochlear implants, metal fragments or foreign objects in the eyes, skin or body).

Following the first round of onsite PISA detailed neuropsychology and imaging (multi-dimensional MRI \& amyloid PET) (described below), a second clinical consensus meeting is held to establish the blinded clinical diagnosis based on current criteria for MCI and AD (Albert et al., 2011; McKhann et al., 2011). Importantly, this occurs prior to divulging amyloid PET, which "unblinds" the clinicians to the presence or absence of amyloid deposition and may otherwise bias appraisal towards or away from a presumptive clinical diagnosis of $\mathrm{AD}$.

\subsubsection{Onsite assessment overview}

All participants, both genetically enriched and clinical cohorts, attend their first visit at QIMR Berghofer in Herston, QLD. After an overnight fast, the participant arrives at an allocated time and discusses the study in detail with a member of the research team before providing informed consent for all aspects of the study. A blood sample is donated and physical measures are collected, including height, weight, blood pressure and pulse (seated and standing), hip and waist measurements, and fat mass and percentage. Participants are provided with breakfast and are then walked a short distance to the Herston Imaging Research Facility (HIRF) where they participate in the MRI protocol and neuropsychological testing. The timing and order of MRI and Neuropsychological assessments is organised around imaging slots and neuropsychologist availability, to maximise the number of participants that can be assessed each day. All participants are invited to return two to three months later for the MRI amyloid PET scan. There is a low dropout rate at this stage of the study, with $91 \%$ of participants returning for the amyloid PET scan. When participants attend their second visit, they receive a sleep sensing device to measure resting heart rate and sleep quality over five months.

\subsubsection{Multimodal imaging}

A summary of the MRI parameters is shown in Table 3.

\section{MRI (PRISMA)}

Imaging data are acquired on a $3 \mathrm{~T}$ Siemens Prisma System (Siemens Healthineers, Erlangen, Germany) with the body coil for signal transmission and a 64-channel head coil and 18-channel body coil for signal reception (software version VE11). The following sequences are acquired:

T1-weighted structural brain images are acquired with the MP2RAGE sequence $(\mathrm{TE} / \mathrm{TR}=2.96 \mathrm{~ms} / 5 \mathrm{~s}$, TI2/TI2 $=0.701 \mathrm{~s} / 2.5 \mathrm{~s}$, $\mathrm{FA} 1 / \mathrm{FA} 2=4^{\circ} / 5^{\circ}, 1 \mathrm{~mm}$ isotropic resolution, acquisition matrix 256 $\times 240 \times 192, \mathrm{BW}=240 \mathrm{~Hz} / \mathrm{Px}, 3 x \mathrm{GRAPPA}$ acceleration) (Marques et al., 2010). MP2RAGE imaging is used to increase the consistency of the longitudinal and multi-centric data compared to that provided 
Table 3

Summary of PISA MRI sequences. *Scans acquired on the PET/MRI.

\begin{tabular}{|c|c|c|c|c|c|c|c|}
\hline Sequence Name & Acquisition Time(min:sec) & Matrix size $\left(\mathrm{mm}^{3}\right)$ & Voxel size $\left(\mathrm{mm}^{3}\right)$ & $\mathrm{TE}$ (msec) & TR (msec) & FA (degree) & TI (msec) \\
\hline 3D MP2RAGE & 9:02 & $256 \times 240 \times 192$ & $1 \times 1 \times 1$ & 2.98 & 5000 & $4 / 5$ & $701 / 2500$ \\
\hline 3D FLAIR & $7: 07$ & $256 \times 256 \times 192$ & $1 \times 1 \times 1$ & 388 & 5000 & 4 & 1800 \\
\hline 3D 9-echo-GRE & $8: 43$ & $224 \times 182 \times 144$ & $1 \times 1 \times 1$ & $\begin{array}{l}5.84 \\
4.79 \\
44.16\end{array}$ & 50 & 15 & - \\
\hline 2D Diffusion & $10: 00$ & $244 \times 244 \times 148$ & $2 \times 2 \times 2$ & 84 & 4700 & 90 & - \\
\hline 2D Bold-Task fMRI & $13: 38$ & $206 \times 206 \times 144$ & $2.4 \times 2.4 \times 2.4$ & 33 & 820 & 53 & - \\
\hline 3D Dixon & $0: 26$ & $320 \times 220 \times 144$ & $1.2 \times 1.2 \times 3.0$ & $\begin{array}{l}1.29 \\
2.52\end{array}$ & 3.97 & 9 & - \\
\hline 3D MPRAGE* & $5: 03$ & $256 \times 240 \times 192$ & $1 \times 1 \times 1$ & 2.26 & 2300 & 8 & 900 \\
\hline rs-fMRI * & $10: 05(20: 31)$ & $220 \times 220 \times 42$ & $3.1 \times 3.1 \times 3.0$ & 30 & 2680 & 90 & - \\
\hline PC-ASL* & $9: 58$ & $220 \times 220 \times 27$ & $3.4 \times 3.4 \times 4.0$ & 13 & 5100 & 90 & - \\
\hline
\end{tabular}

by the MPRAGE sequence (Okubo et al., 2016). In addition, the MP2RAGE sequence provides T1 relaxation time measurements of brain tissues that are potential biomarkers of ageing and neurodegeneration (Tang et al., 2018).

T2-weighted fluid attenuation inversion recovery (FLAIR) images are included to assess white matter hyperintensity (WMH) burden, and parameters are as follows: $\mathrm{TE} / \mathrm{TR}=388 / 5000 \mathrm{~ms}, \mathrm{FA}=120^{\circ}$, acquisition matrix $=256 \times 256 \times 192,1.0 \mathrm{~mm}$ voxel isotropic. Multi-shell diffusion-weighted images (DWI) are acquired using parameters: TE/TR $=84 / 4700 \mathrm{~ms}$, FOV $244 \mathrm{~mm}$, acquisition matrix $122 \times 122,74$ slices, slice thickness $2.0 \mathrm{~mm}, \mathrm{FA}=90^{\circ}$. The acquisition includes 12 non-diffusion weighted images $\left(b=0 \mathrm{~s} / \mathrm{mm}^{2}\right)$ as well as $20\left(\mathrm{~b}=1000 \mathrm{~s} / \mathrm{mm}^{2}\right), 32\left(\mathrm{~b}=2000 \mathrm{~s} / \mathrm{mm}^{2}\right)$, and $60(\mathrm{~b}=$ $3000 \mathrm{~s} / \mathrm{mm}^{2}$ ) unique directions. These are split across four blocks with alternating AP/PA phase encoding directions for the purpose of post-acquisition distortion correction.

A 3D gradient-recall echo (GRE) sequence are acquired with TE1/ $\Delta \mathrm{TE} / \mathrm{TE} 9 / \mathrm{TR}=5.84 / 4.79 / 44.16 / 50 \mathrm{~ms}, \mathrm{FA}=15^{\circ}$, acquisition matrix $182 \times 224 \times 144$, GRAPPA acceleration factor $=3$, BW $=310$ $\mathrm{Hz} / \mathrm{Px}$ and flow compensation only to the first echo. The GRE sequence was acquired with true-axial orientation. The phase data from individual channels were combined properly using a reference image acquired by the body coil.

Task-based functional MRI data are acquired while participants view news clips. In brief, participants view the second half of 18 short news clips, having viewed the first half of 9 of these clips ten minutes earlier. These gradient echo data are acquired using the Siemens multi-slice acquisition with the following parameters: TR/TE $=820$ $\mathrm{ms} / 33.0 \mathrm{~ms}$, flip angle $=53 \mathrm{deg}$, slices $=72$, voxel size $2.4 \times 2.4 \times$ $2.4 \mathrm{~mm}$, SMS factor $=6$, acquisition direction PA plus two spin echo volumes with inverse PED (AP\&PA) acquired for distortion correction. Brain regions activations are derived from the contrast of continuous (previous) viewing versus naïve (new) viewing. Further details of the task are provided in Appendix C.1.

In addition to the brain imaging, a two-point DIXON sequence is included to image the abdominal region between vertebral bodies T11 and L5 for assessment of visceral obesity. The acquisition is divided into two overlapping image slabs with the following parameters: TE1/TE2/TR $=1.29 / 2.52 / 3.97 \mathrm{~ms}, \mathrm{FA}=9^{\circ}$, acquisition matrix $320 \times 220 \times 144, \mathrm{BW}=1040 \mathrm{~Hz} / \mathrm{Px}$, voxel size $1.2 \times \times 1.2$ $\mathrm{mm}$ and $3.0 \mathrm{~mm}$ slice thickness.

Pet/MRI

The positron emission tomography (PET) scans are performed on a Biograph mMR hybrid scanner (Siemens Healthineers, Erlangen, Germany) with Fluorine-18 florbetaben ( $\left.\left[{ }^{18} \mathrm{~F}\right] \mathrm{FBB}\right)$, a diagnostic radiotracer which possesses a highly selective binding for $\beta$-amyloid in neural tissue (Fodero-Tavoletti et al., 2012; Rowe et al., 2008).

With participants seated in a quiet room, $300+/-10 \% \mathrm{MBq}[18 \mathrm{~F}]-$ Florbetaben is injected via an intravenous line inserted into a vein in the participant's arm or hand. A 20-minute scan was acquired starting at
90 min post injection of [18F]-Florbetaben. The total PET/MR session takes $30 \mathrm{~min}$ to complete. PET counts are acquired using the Siemens mMR avalanche photodiodes (APDs).

For the concurrent MR, an MR UTE scan is first acquired for attenuation correction. Additionally, a T1-weighted structural image is acquired with the MPRAGE sequence (TE/TR $=2.26 \mathrm{~ms} / 2.3 \mathrm{~s}$, T1 $=0.9 \mathrm{~s}$, $\mathrm{FA}=8^{\circ}, 1 \mathrm{~mm}$ isotropic resolution, matrix $256 \times 240 \times 192, \mathrm{BW}=200$ $\mathrm{Hz} / \mathrm{Px}, 2 \mathrm{x}$ GRAPPA acceleration) (Mugler and Brookeman, 1990). Two functional MRI sequences are then acquired in parallel with PET acquisition. From a subset of subjects, either a $20 \mathrm{~min}$ or $10 \mathrm{~min}$ resting state BOLD scan is acquired with a $2 \mathrm{D}$ echo planar sequence (TE/TR = $30 \mathrm{~ms} / 2680 \mathrm{~ms}, \mathrm{FA}=90^{\circ}, 3.1 \times 3.1 \times 3 \mathrm{~mm}$ resolution, matrix $220 \times$ $220 \times 42, \mathrm{BW}=2240 \mathrm{~Hz} / \mathrm{Px}, 223$ temporal images). From all other subjects, a $10 \mathrm{~min}$ rs-fMRI is acquired, followed by a $10 \mathrm{~min}$ resting state arterial spin labelling scan using a pseudo continuous arterial spin labelling with a $2 \mathrm{D}$ echo planar readout (TE/TR $=13 \mathrm{~ms} / 5100 \mathrm{~ms}$, post labelling delay $=1300 \mathrm{~ms}$, labelling duration $1500 \mathrm{~ms}, \mathrm{FA}=90^{\circ}, 3.4 \times$ $3.4 \times 4 \mathrm{~mm}$ resolution, matrix $220 \times 220 \times 27,6 / 8$ partial fourier, BW $=2298 \mathrm{~Hz} / \mathrm{Px}, 117$ temporal images). These sequences allow for motion correction of the PET images and also yield resting state BOLD and CBF images for independent analyses.

All imaging data are pre-processed using a common qualitycontrolled pipeline which integrates standard and customised steps (see Appendices sections C.2 and C.3 for further details)

\section{Imaging data storage}

DICOM images from the PRISMA and PET/MRI are collated and checked with in-house software (milxStager) for consistency with the predefined imaging protocol. DICOM data that passes consistency checks is then anonymised, converted to NIFTI and uploaded to an XNAT database (Marcus et al., 2007). RAW DICOMs are archived onto CSIRO servers. All subsequent processing is completed using data that is available on XNAT.

\subsubsection{Biological samples}

Participants in the PISA onsite cohort have blood samples collected to a maximum of $80 \mathrm{ml}$ and utilised as shown in Fig. 2. Serum aliquots for biochemical testing are forwarded to a clinical pathology lab (Pathology Queensland, Royal Brisbane and Women's Hospital). The full tests carried out are described in detail in Appendix D.

All samples are routinely $A P O E$ genotyped using the method described above, providing new data for the clinical cohort and confirming genotypes for the genetically enriched cohort. In addition clinical cohort samples are genotyped with a genome wide SNP array (Illumina Global Screening Array with Multi-disease drop-in, chip version GSAMD-24v1-0_20011747) in batches and imputed to the HRC r1.1 reference panel (McCarthy et al., 2016).

\subsubsection{Onsite neuropsychology}

Cognitive and mood assessments for PISA Onsite participants are 


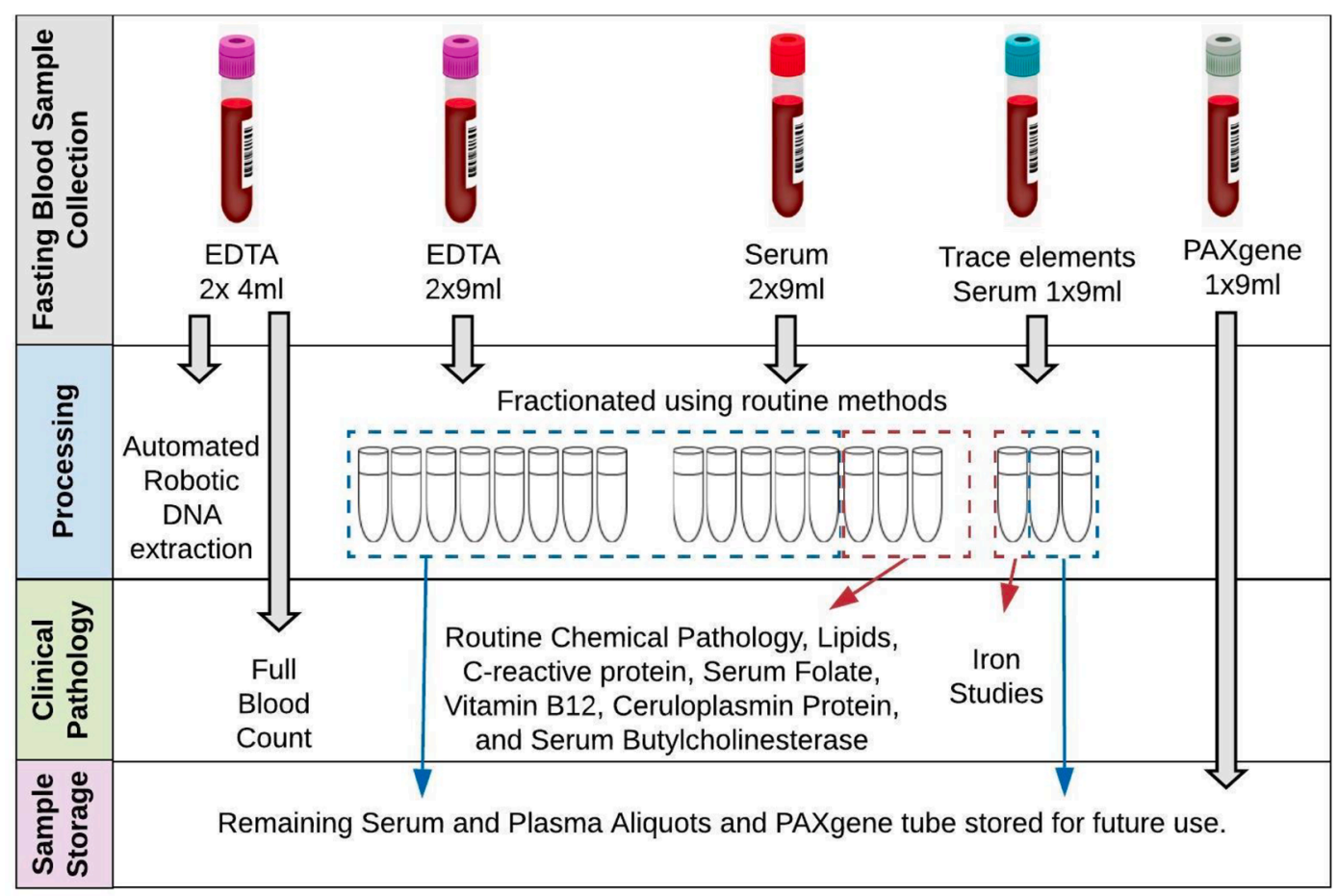

Fig. 2. PISA Onsite blood sample collection and processing.

conducted by trained neuropsychologists. Participants complete a range of standardized tests selected to measure the main cognitive domains that typically decline in the typical amnestic form of AD and atypical non-amnestic presentations (language, visuospatial and executive dysfunction (McKhann et al., 2011)). We highlight that non-amnestic cognitive abilities are integral for memory test performance because executive functions such as attention and strategic processes are required to efficiently encode and retrieve memories and information to be recalled can be verbal or visual, implicating language and visuospatial cognitive skills. In addition, tests were chosen on the basis that they will enable comparison and harmonization with other large-scale and longitudinal studies; possess robust psychometric properties; and be sensitive to longitudinal change. A select number of tests were included as proxies for cognitive reserve (e.g. reading) or that are theoretically motivated by recent neuropsychological lesion studies which implicate left/right lateral prefrontal regions in specific executive functions (e.g., Fluency and Hayling Sentence Completion Tests; (Robinson et al., 2012, 2015a)). Spontaneous speech samples are collected to measure language and propositional (idea) density; the number of ideas and connection or coherence between ideas (Barker et al., 2017). In the seminal Nun study, lower propositional density in younger adulthood was shown to predict poor cognitive performance in later life and, at autopsy, confirmed AD neuropathology (Snowdon et al., 1996). All tests are administered in person, then scored and transcribed (speech samples). Summary data is entered into spreadsheets with quality control checks.

The neuropsychological tests were selected based on their published psychometric properties (Table 4). Thus, we anticipate that each test will load primarily onto the domains they are listed under in Table 4. Of note, each domain comprises several tests, even if only one is explicitly identified. For example, visual perception is assessed by at least three measures (i.e., WASI-II Matrix Reasoning, cube analysis and TEA Telephone Search). Importantly, single neuropsychological test scores are required for the diagnosis of $\mathrm{MCI}$ and $\mathrm{AD}$ and all PISA participants (healthy and clinical) are checked against diagnostic criteria. Single test scores are also important and useful for theoretically derived analyses. Not all tests within each domain measure the same aspect of cognition.
Table 4

PISA onsite Neuropsychology assessment.

\begin{tabular}{|c|c|}
\hline Domain & Tests \\
\hline $\begin{array}{l}\text { General } \\
\text { Intelligence }\end{array}$ & $\begin{array}{l}\text { Wechsler Abbreviated Scale of Intelligence }-2^{\text {nd }} \text { Edition (WASI- } \\
\text { II). } 2 \text { sub-tests: Similarities, Matrix Reasoning) (Wechsler, 2011) }\end{array}$ \\
\hline Memory & $\begin{array}{l}\text { Episodic Verbal - Rey Auditory Verbal Learning Test (Ivnik et al., } \\
\text { 1990) } \\
\text { Visual - Topographical Recognition Memory Test (Warrington, } \\
\text { 1996) } \\
\text { Working Memory: Wechsler Adult Intelligence Scale - Fourth } \\
\text { Edition (WAIS-IV; Digit Span F/B) (Wechsler, 2003) }\end{array}$ \\
\hline Language & $\begin{array}{l}\text { Naming - Graded Naming Test (Warrington, 1997) } \\
\text { Spontaneous speech - complex scene description - Beach Scene ( } \\
\text { Robinson et al., 2015b) }\end{array}$ \\
\hline $\begin{array}{r}\text { Literacy and } \\
\text { Numeracy }\end{array}$ & $\begin{array}{l}\text { Oral Graded-Difficulty Spelling Test (Baxter and Warrington, } \\
\text { 1994) } \\
\text { Oral-Graded-Difficulty Arithmetic Test (Jackson and } \\
\text { Warrington, 1986) } \\
\text { National Adult Reading Test (NART) (Nelson and Willison, } \\
\text { 1991) }\end{array}$ \\
\hline $\begin{array}{l}\text { Executive } \\
\text { Functions }\end{array}$ & $\begin{array}{l}\text { Word fluency- FAS; Animals (Tombaugh et al., 1999) } \\
\text { Stroop Test (Victoria version) (Troyer et al., 2006) } \\
\text { Hayling Sentence Completion Test (Burgess and Shallice, 1997) }\end{array}$ \\
\hline $\begin{array}{l}\text { Psychomotor } \\
\text { Speed }\end{array}$ & Symbol Digit Modality Test (Smith, 1973) \\
\hline $\begin{array}{l}\text { Visual } \\
\text { Perception }\end{array}$ & Cube Analysis (VOSP) (Warrington and James, 1991) \\
\hline Attention & TEA: Telephone Search; Dual Task (Robertson et al., 1994) \\
\hline $\begin{array}{l}\text { Social Cognition } \\
\text { and Emotion } \\
\text { Recognition }\end{array}$ & $\begin{array}{l}\text { Mini-SEA emotion evaluation (Bertoux et al., 2014) } \\
\text { TASIT-S part B Sarcasm (McDonald et al., 2017) }\end{array}$ \\
\hline $\begin{array}{l}\text { Current Mood } \\
\text { Symptoms }\end{array}$ & $\begin{array}{l}\text { Hospital Anxiety and Depression Scale (HADS) (Snaith and } \\
\text { Zigmond, 1994) }\end{array}$ \\
\hline
\end{tabular}

For example, while the Stroop task and Hayling Test are measures of verbal inhibition, the Hayling Test has both a semantic component and a measure of initiation, while the Stroop task is more visually based. Phonemic verbal fluency and semantic verbal fluency likewise are similar tasks although known to load differently onto the brain (Robinson et al., 2012). Comparing group performance on single tasks is a valid and useful approach to test theoretical questions of cognition and 
brain function while domain composite scores are useful and a robust way for predicting group fit (e.g. predicting amyloid status). From the list of single tests, researchers will be able to create composite scores within cognitive domains if that is appropriate for their particular analysis and research question.

All participants are asked screening questions about everyday function in activities and changes to functional or cognitive capacity to corroborate that they are in the healthy or clinical cohort. The length of assessment is typically two hours for healthy participants and three hours for the clinical cohort.

\subsubsection{Smart sensing}

Recent research demonstrates a bidirectional relationship between sleep and AD pathology, with supporting evidence showing that changes in sleep patterns occur from the preclinical stage of $\mathrm{AD}$ (Ning and Jorfi, 2019). The co-occurrence of sleep disturbances and amyloid-beta (A $\beta$ ) accumulation suggest the importance of monitoring sleep patterns in adults who are at high-risk of developing neuro-degenerative disorders later in life.

Polysomnography (PSG) is the gold standard in measuring sleep parameters. However, there are several limitations in using PSG for longitudinal sleep monitoring. It is expensive, intrusive, and may lead to disturbed sleep patterns, due to an unfamiliar laboratory environment. Pervasive or ubiquitous sensors are an alternative choice for measuring sleep on a long-term basis due to low cost, and minimal obtrusion in a participant's usual environment.

PISA onsite participants are given a contact-free sleep monitoring device when they return on-site for their PET scan. The EMFIT QS (Quantified Sleep) (Emfit, Filand) (Ranta et al., 2019) sleep monitor consists of a thin ferroelectric sensor that is placed underneath a bed mattress to perform at-home monitoring of sleep patterns. During their visit, participants are provided with verbal and written instructions on how to set up and use the device. The EMFIT QS connects to the participants' home Wi-Fi and regularly transmits data to the research team. The device collects continuous resting heart rate and respiration rate, sleep stage estimates, sleep duration, sleep latency, waking rate and number of bed exits throughout the night. The heart rate and respiration rate measured by EMFIT QS has been validated against PSG measurements (Ranta et al., 2019).

So far, 168 PISA participants have been offered an EMFIT QS device. Of these, 102 participants completed the study, 50 participants declined due to Wi-Fi availability and/or privacy concerns, and 16 participants are currently using the device. The participants are given a reply-paid postage bag with the device and instructed to return the device when 5 months of data collection has been completed. The 5 month time frame allows a balance between the collection of representative data and the use of available sensors for additional participants.

The aim of the smart sensing stream is to understand the changes in sleep pattern across the spectrum of $\mathrm{AD}$, from the preclinical stage to late-onset $\mathrm{AD}$, and to investigate the impact of altered sleep in disease progression in $\mathrm{AD}$. To do so, we introduce a sleep disruption index as a quantitative measure for significant changes in sleep patterns based on the collected data from the EMFIT QS.

\subsubsection{Bioinformatics}

PISA phenotypic data are collated into a central RedCAP database (Harris et al., 2009). This includes basic MRI-derived measurements (such as hippocampal volume, white matter lesion volume, and ventricular volume) from imaging pipelines which are uploaded into RedCAP either as batch uploads or automatically at the end of the processing pipeline. Any manual annotations relevant to imaging acquisition (e.g. subject was claustrophobic, scan was cancelled after 20 min) are also uploaded. Results of the blood tests are automatically uploaded from HL7v2 files received from the pathology lab, preventing the need for manual entry and reducing data entry errors. All Additional PISA onsite phenotypic data are batch uploaded into RedCAP.
Measurement data in RedCAP is periodically locked down and cross checked to ensure no errors have propagated during measurements and data entry. This is carried out both manually and via automated scripts which examine the distribution of values and mark any outliers to be cross-checked. Data is made available for download to PISA investigators and collaborators using a web-based portal.

\section{Results}

\subsection{Results overview}

This is a first overview of our current sample sizes and demographic data as of the 21st of August 2020 from participants recruited for PISA online and the baseline of PISA onsite. Recruitment for both is ongoing, and the follow-up time point for PISA onsite (two years after the baseline visit) is now underway.

\subsection{Results PISA online}

The online survey was launched on the 4th of July 2017. The current participation rate is $28 \%$. To date, 3801 participants have taken part in the core survey with $65 \%$ of those going on to complete all additional modules (Fig. 3). The demographic information for participants who have completed the core module is given in Table 2. Ethnicity is predominantly Caucasian due to a prerequisite for Caucasian ancestry in the previous genetic studies which form the recruitment pool. Sample size will increase as the follow up of non-responders is ongoing, and includes provision of paper copies of the questionnaire if required.

Preliminary assessment of recruitment bias for PISA online shows significant associations of older age $(\beta=0.01, \mathrm{SE}<0.001, \mathrm{P}<0.001)$ and female sex $(\beta=0.01, \mathrm{SE}<0.001, \mathrm{P}<0.001)$ with participation in the study. No association was identified with the Alzheimer's polygenic risk score (PRS) or APOE $\varepsilon 4$ carrier status.

Participants who have completed the online survey are also approached to complete online cognitive assessments. Currently 1956 participants have taken part in the CBS assessment (62\% participation rate from 3176 who have been approached), 437 in Cogstate (26\% of 1654 approached), and 927 completed the Emotion Recognition Task (56\% of 1654 approached), with recruitment and follow-up ongoing. Low recruitment numbers for cogstate are partly due to a requirement for a computer (rather than tablet) and implementation problems with some operating systems on participants' home computers.

\subsection{Results PISA onsite baseline}

To date 281 participants have completed baseline onsite assessments for PISA onsite. Of these 48 are clinical participants and 233 are genetically enriched (selected from those who have completed the online survey). Participant demographics are shown in Table 5.

Preliminary results for select baseline neuropsychology tests for the genetically enriched participants indicate a wide range of scores on the majority of tasks, with the mean of all tasks falling within or above the average range on all tasks based on the available published norms (Table 6). This provides confidence that our test battery is satisfactory and canvasses reasonable variability in cognitive function.

As an illustrative analysis of the baseline MRI data, we regressed sulcal width against age (and age squared) for the 202 healthy participants (genetically enriched cohort) of which the T1w MPRAGE MRI scans are currently available (Fig. 4). In particular, the width of 64 individual sulci were extracted using the Morphologist pipeline of the Brainvisa toolbox (Borne et al., 2020). Correlations against age and age squared were derived across the sample and corrected for multiple comparisons using the Benjamini-Hochberg false discovery rate correction. Consistent with prior work (Good et al., 2001), the effect of age on cortical anatomy is widespread, although heterogenous. 43 of the sulci (out of 64) are significantly correlated with age (vs. 44 for age 


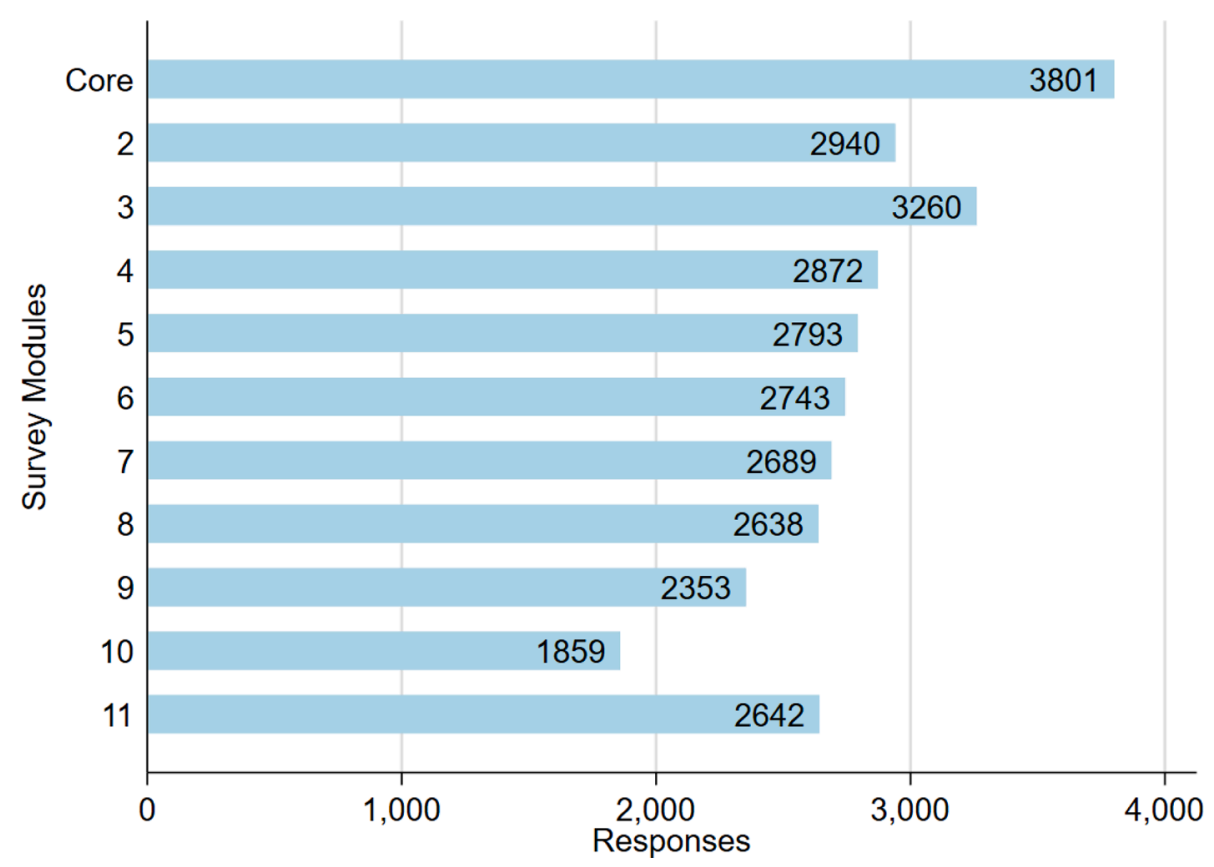

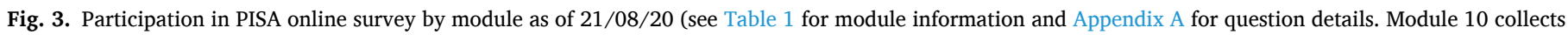
information on women's health and therefore shows reduced participation because is completed by women only).

squared). Increasing width with age was strongest in the insula, lateral fissure, precentral sulcus, calcarine fissure and superior temporal sulcus. The regression against the age squared term has a positive coefficient and thus suggests an accelerating rate of sulci expansion in this population.

The follow-up time point phenotyping is currently underway, with 104 participants currently approached, giving an $88 \%$ retainment rate thus far (92 participants have completed follow-up assessments, 2 have become ineligible and 10 have withdrawn).

\section{Discussion}

The primary outcome of the PISA study is to establish a longitudinal cohort of healthy midlife-elderly individuals at high genetic risk of dementia. This will be a unique international resource - only enabled by the recent breakthroughs in genetic analysis - and will yield new possibilities for basic and translational research. This protocol and cohort are of broad significance for other investigations - particularly clinical trials in dementia prevention.

PISA is not designed to test specific hypotheses regarding genetic risk, phenotype and brain, but rather to complement other discoveryoriented cohort studies such as the UK biobank: Focussing specifically on $\mathrm{AD}$ allows deeper phenotyping and imaging of $\mathrm{AD}$-specific features. As such, the size of the cohort (currently $\mathrm{N}=281$, of which 233 are from the genetically enriched arm) was not predetermined by a specific power calculation. However, recent studies suggest PISA is well powered to detect core candidate effects. For example, slower rates of hippocampal atrophy and higher levels of CSF A $\beta$ were recently detected in cognitively normal older $A P O E \varepsilon 2$ carriers $(N=27$ APOE $\varepsilon 2 / \varepsilon 2$ or $\varepsilon 2 / \varepsilon 3$, versus $N=107 A P O E \varepsilon 3 / \varepsilon 3$ ) (Chiang et al., 2010); Relative to $\mathrm{A} \beta+\varepsilon 4$ noncarriers $(N=36), \mathrm{A} \beta+\varepsilon 4$ carriers $(N=48)$ showed significantly faster decline on memory tasks (Lim et al., 2015). An association between AD PRS and smaller left hippocampal volume, remained when the APOE gene was excluded ( $N=272$ ) (Foley et al., 2017). Similarly, ADspecific cortical thinning was correlated with the AD polygenic risk score, even after controlling for $A P O E$ genotype and cerebrospinal fluid (CSF) levels of $\beta$-amyloid $(N=104)$ (Sabuncu et al., 2012).We also aim to progressively increase the sample size of PISA through ongoing recruitment, and lengthen and increase longitudinal sampling, subject to funding.

The age range of the genetically enriched cohort spans from midlife to older adults, encompassing a range of individuals at different levels of risk for $\mathrm{AD}$, with a considerable variance IQ and cognitive function. Recent work has shown that high levels of neocortical $A \beta$-amyloid occur at age 72, but earlier (at age 63) for APOE $\varepsilon 4$ carriers (Burnham et al., 2020), suggesting that our healthy cohort should also include a substantial proportion of individuals with $A \beta$-amyloid. Using advanced structural, functional, and molecular imaging technologies, this will enable characterizing the neurobiological features associated with high risk for dementia and, in particular, identify those changes associated with the initial onset of cognitive impairment in those high-risk participants as they begin the transition to $\mathrm{AD}$. Together with genetic risk prediction, such knowledge has clear potential to develop prognostic markers for dementia development.

While we study the interplay between genetic and environmental factors for dementia, we also aim to identify those risk factors (e.g. lifestyle) that could be modified through intervention. Recent evidence points to several important modifiable risk factors for $\mathrm{AD}$ including education level, hypertension, hearing impairment, smoking, obesity, depression, physical inactivity, diabetes, low social contact, excessive alcohol consumption, traumatic brain injury, and air pollution (Livingston et al., 2020). The multimodal imaging, behavioural, neuropsychological and sleep data will be a unique resource to assist in understanding the complex and dynamic relationship between neurobiological antecedents of dementia at high risk and the subsequent progression to cognitive impairment. In addition, the acquisition and storage of DNA, RNA (PAX gene tube), serum and plasma will allow for future work including epigenetics, gene expression, and blood based biomarkers.

Limitations of the PISA study include that the genetically enriched cohort is selected from a database of previous research participants who originally consented to be part of a prior research study, allowed recontact and then consented to take part in PISA. This multi-stage recruitment process will likely inflate any selection bias related to willingness to participate in research studies. In addition, characteristics of the original studies' participant selection will be reflected in PISA participants including geographical locations, the inclusion of twins and relatives of twins, the large proportion of female participants (due to 
Table 5

Participant demographics for PISA as of 21/08/20. For PISA online, data shown for all individuals who have completed the core module of the online survey.

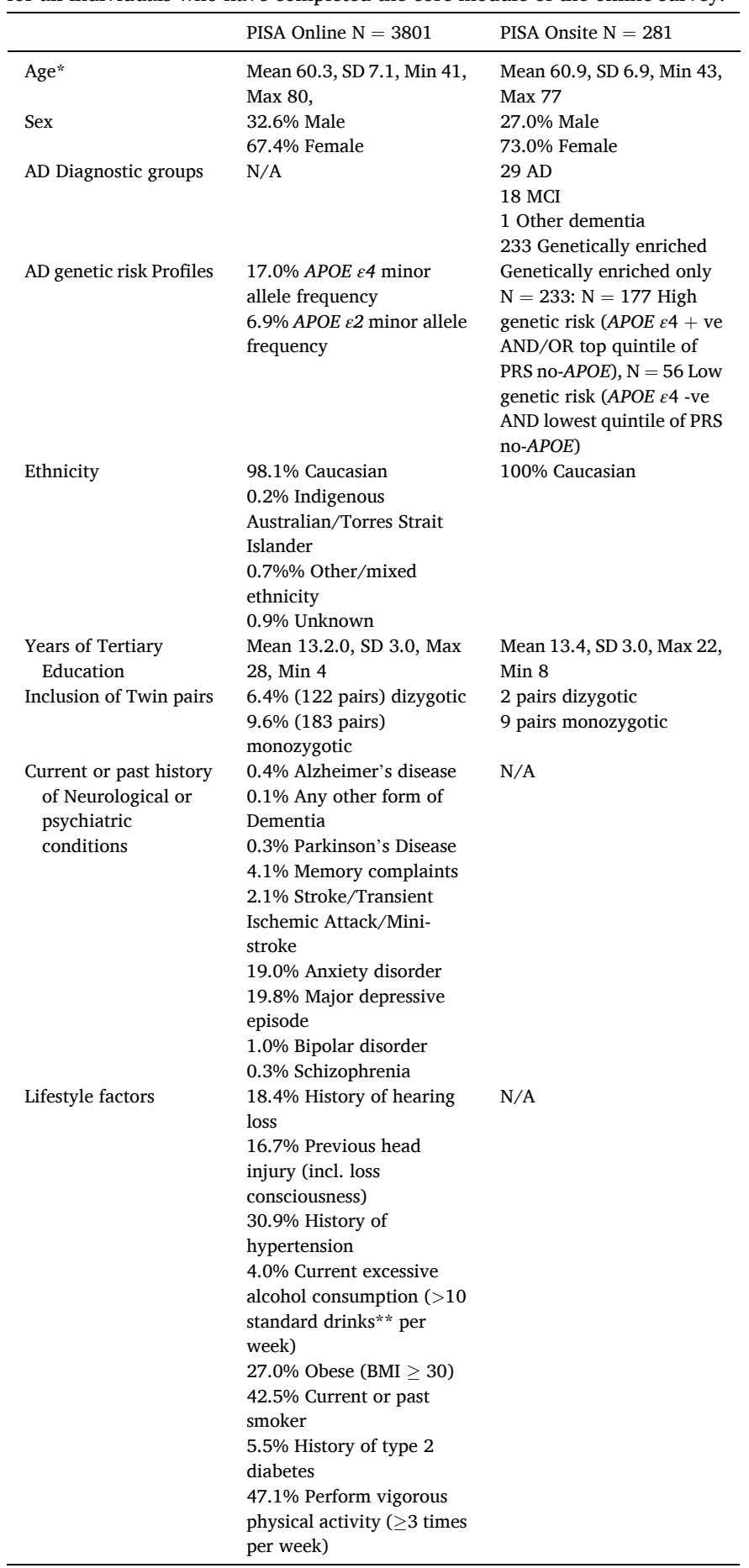

**Age is age at MRI scan, a small subset of participants have an age greater than that specified in the recruitment criteria due to the delay between first contact and the onsite visit.

*Standard drinks according to the Australian standard, equivalent to 1.27 unit drink in the UK and 0.714 standard drinks in the USA.

increased rates of females volunteering for research over males, over two recruitment occasions) and the predominance of Australians of Caucasian ethnicity. For the PISA onsite genetically enriched cohort individuals who are at both high and low genetic risk of $\mathrm{AD}$ were purposely selected. Therefore, rather than a traditional case/control design where the controls are representative of the normal population, this
Table 6

PISA onsite baseline neuropsychology scores for the genetically enriched cohort.

\begin{tabular}{|c|c|c|c|}
\hline Domain & Tests & $\mathrm{M}(\mathrm{SD})$ & Descriptor \\
\hline $\begin{array}{l}\text { General } \\
\text { Intelligence }\end{array}$ & WASI-II IQ: Standard Score & $\begin{array}{l}104.26 \\
(10.40)\end{array}$ & Average \\
\hline \multirow[t]{3}{*}{ Memory } & $\begin{array}{l}\text { Rey Auditory Verbal Learning } \\
\text { Test: Total Learning (z-score) }\end{array}$ & $\begin{array}{l}0.05 \\
(1.05)\end{array}$ & Average \\
\hline & $\begin{array}{l}\text { Topographical Recognition } \\
\text { Memory: Test Total correct ( } \\
\text { Warrington, 1996) }\end{array}$ & $\begin{array}{l}26.08 \\
(2.93)\end{array}$ & $\begin{array}{l}\text { Average/High } \\
\text { average }\end{array}$ \\
\hline & Digit Span Forward: Scaled Score & 11.00 & Average \\
\hline \multirow[t]{2}{*}{ Language } & $\begin{array}{l}\text { Graded Naming Test: Total } \\
\text { correct }\end{array}$ & $\begin{array}{l}21.63 \\
(3.44)\end{array}$ & Average \\
\hline & $\begin{array}{l}\text { Spontaneous speech: Words per } \\
\text { minute }\end{array}$ & $\begin{array}{l}130.17 \\
(33.91)\end{array}$ & $\begin{array}{l}\text { Within } \\
\text { normal limits }\end{array}$ \\
\hline \multirow{4}{*}{$\begin{array}{l}\text { Literacy and } \\
\text { Numeracy }\end{array}$} & Oral Graded-Difficulty Spelling & 23.70 & Average \\
\hline & Test: Total correct & (4.09) & \\
\hline & $\begin{array}{l}\text { Oral Graded-Difficulty } \\
\text { Arithmetic Test Total correct }\end{array}$ & $\begin{array}{l}13.81 \\
(5.04)\end{array}$ & Average \\
\hline & NART FSIQ Equivalent & $\begin{array}{l}109.30 \\
(8.66)\end{array}$ & $\begin{array}{l}\text { Average/High } \\
\text { average }\end{array}$ \\
\hline \multirow[t]{3}{*}{$\begin{array}{l}\text { Executive } \\
\text { Functions }\end{array}$} & Word fluency FAS Total & $\begin{array}{l}42.37 \\
(11.50)\end{array}$ & Average \\
\hline & Stroop Test Interference z-score & $\begin{array}{l}0.41 \\
(0.72)\end{array}$ & Average \\
\hline & $\begin{array}{l}\text { Hayling Sentence Completion } \\
\text { Test: Overall Scaled Score }\end{array}$ & $\begin{array}{l}5.60 \\
(1.19)\end{array}$ & Average \\
\hline $\begin{array}{l}\text { Psychomotor } \\
\text { Speed }\end{array}$ & $\begin{array}{l}\text { Symbol Digit Modality Test Total } \\
\text { correct }\end{array}$ & $\begin{array}{l}50.31 \\
(8.63)\end{array}$ & Average \\
\hline $\begin{array}{l}\text { Visual } \\
\text { Perception }\end{array}$ & Cube Analysis: Total correct & $\begin{array}{l}9.71 \\
(0.95)\end{array}$ & $\begin{array}{l}\text { Within } \\
\text { normal limits }\end{array}$ \\
\hline Attention & $\begin{array}{l}\text { TEA: Telephone Search Scaled } \\
\text { Score }\end{array}$ & $\begin{array}{l}11.50 \\
(2.76)\end{array}$ & Average \\
\hline Social Cognition & $\begin{array}{l}\text { Mini-SEA emotion evaluation } \\
\text { Total correct }\end{array}$ & $\begin{array}{l}27.93 \\
(3.03)\end{array}$ & Average \\
\hline $\begin{array}{l}\text { Mood } \\
\text { Symptoms }\end{array}$ & HADS Anxiety Score & $\begin{array}{l}5.47 \\
(3.40)\end{array}$ & $\begin{array}{l}\text { Within } \\
\text { normal limits }\end{array}$ \\
\hline
\end{tabular}

method reflects a kind of 'extreme sampling' in terms of genetic risk. For replication purposes, samples can be selectively drawn from other largescale cohorts, for example UK biobank (Sudlow et al., 2015), ADNI (Mueller et al., 2005) and AIBL (Ellis et al., 2009).

In summary, PISA is a genetically enriched study of healthy and midlife adults at high risk of future dementia, funded by the National Health and Medical Research Council. Current funding permits the full baseline acquisition and follow-up at 2 years, on a par with other studies including AIBL (AD case control \& MCI, with an 18mnth follow-up (Ellis et al., 2009)), The Older Australian Twin Study (OATS, elderly population based with a 2 year follow-up (Sachdev et al., 2009)) and the Sydney Memory and Aging Study (MAS, elderly population based, also with a 2 year follow-up (Sachdev et al., 2010)). We expect this 2 year time difference sufficient to detect the strongest within-subject effect of polygene risk on cognitive and structural brain change. Charting nonlinear time-related difference and detecting more subtle effects will indeed require cohort expansion and further follow-up. Achieving our future aim to continue over subsequent waves of data collection and expand on baseline sample size will require additional funding and collaboration.

\section{Data availability}

Following completion of each wave (baseline, follow-up) and appropriate quality control, de-identified PISA data will be made available to other research groups upon request. Due to privacy, confidentiality and constraints imposed by the local Human Research Ethics Committee, a "Data Sharing Agreement" will be required before data will be released. Due to ethics constraints, data will be shared on a project-specific basis. Depending on the nature of the data requested, evidence of local ethics approval may be required. 

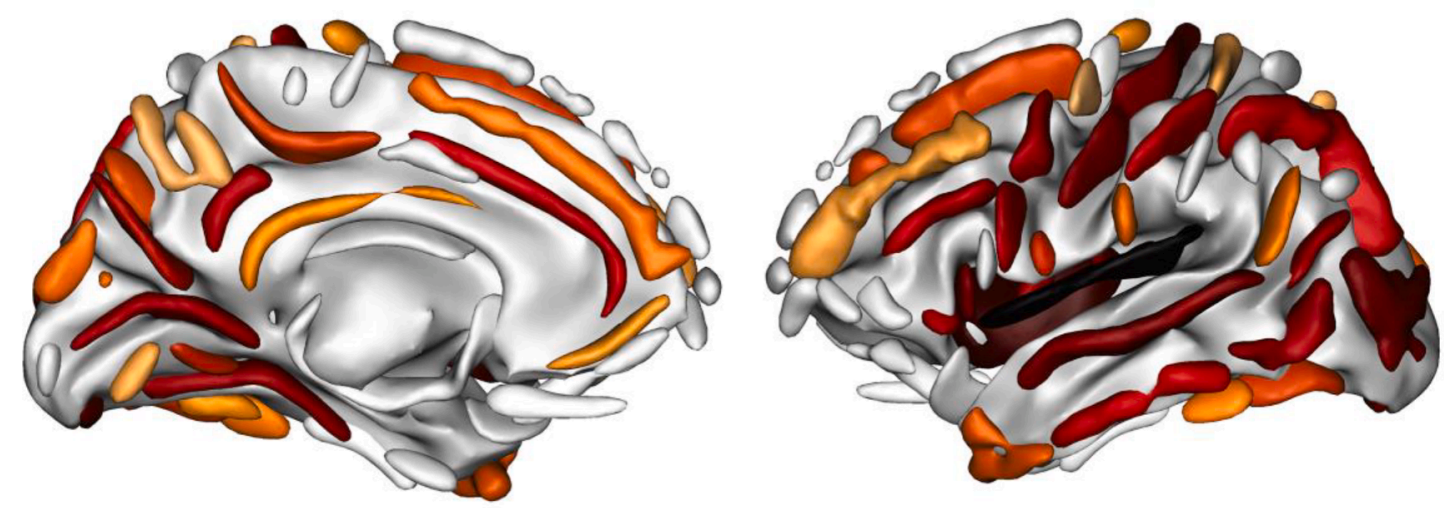

0.1

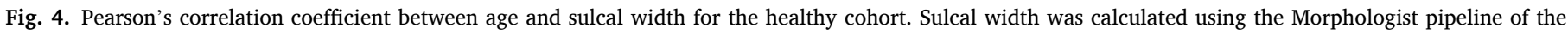

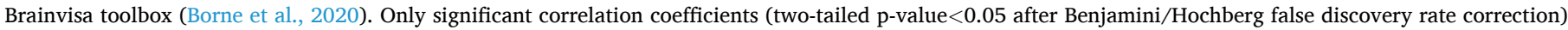
are displayed. As expected, the retained sulci have a positive correlation coefficient.

\section{CRediT authorship contribution statement}

Michelle K. Lupton: Conceptualization, Methodology, Formal analysis, Investigation, Writing - review \& editing, Supervision. Gail A. Robinson: Conceptualization, Methodology, Formal analysis, Investigation, Writing - review \& editing, Funding acquisition. Robert J. Adam: Resources, Writing - review \& editing. Stephen Rose: Conceptualization, Writing - review \& editing, Funding acquisition. Gerard J. Byrne: Resources, Writing - review \& editing, Funding acquisition. Olivier Salvado: Conceptualization, Writing - review \& editing, Funding acquisition, Funding acquisition. Nancy A. Pachana: Conceptualization, Writing - review \& editing, Funding acquisition. Osvaldo P. Almeida: Conceptualization, Writing - review \& editing, Funding acquisition. Kerrie McAloney: Investigation, Data curation, Writing review \& editing, Supervision, Project administration. Scott D Gordon: Data curation, Writing - review \& editing. Parnesh Raniga: Data curation, Writing - review \& editing. Amir Fazlollahi: Formal analysis, Writing - review \& editing. Ying Xia: Formal analysis, Writing - review \& editing. Amelia Ceslis: Formal analysis, Investigation, Data curation, Writing - review \& editing. Saurabh Sonkusare: Investigation, Writing review \& editing. Qing Zhang: Formal analysis, Writing - review \& editing. Mahnoosh Kholghi: Formal analysis, Investigation, Writing review \& editing. Mohan Karunanithi: Formal analysis, Writing - review \& editing. Philip E Mosley: Formal analysis, Resources, Writing review \& editing. Jinglei Lv: Formal analysis, Writing - review \& editing. Léonie Borne: Formal analysis, Writing - review \& editing. Jessica Adsett: Investigation, Data curation, Writing - review \& editing. Natalie Garden: Investigation, Data curation, Writing - review \& editing. Jurgen Fripp: Methodology, Writing - review \& editing, Supervision, Funding acquisition. Nicholas G. Martin: Conceptualization, Methodology, Resources, Writing - review \& editing, Supervision, Funding acquisition. Christine C Guo: Conceptualization, Methodology, Formal analysis, Investigation, Writing - review \& editing, Supervision, Funding acquisition. Michael Breakspear: Conceptualization, Methodology, Formal analysis, Writing - review \& editing, Supervision, Funding acquisition.

\section{Declaration of Competing Interest}

The authors declare that they have no known competing financial interests or personal relationships that could have appeared to influence the work reported in this paper.

\section{Acknowledgments}

PISA is funded by a National Health and Medical Research Council (NHMRC) Boosting Dementia Research Initiative - Team Grant [APP1095227], to MB, NM, GB, SR, CCG, OS, OA, GAR, NP. MKL is supported by a Boosting Dementia Leadership Fellowship [APP1140441]. GAR is supported by a Boosting Dementia Research Leadership Fellowship [APP1135769].

The population based sample for PISA comprises of research participants who have taken part in genetic epidemiology studies led by NM (with colleagues and collaborators) at QIMR Berghofer and elsewhere over the past 40 years. Demographic and contact information as well as genome-wide SNP chip data were utilised from these previous studies for participant selection and recruitment. Principal sources of funding for these early studies were from grants to NGM from Australian NHMRC and to Andrew Heath and Pam Madden (Washington University, St Louis) from NIH (mainly NIAAA and NIDA) and we gratefully acknowledge these contributions.

We thank the International Genomics of Alzheimer's Project (IGAP) for providing $\mathrm{AD}$ meta-analysis summary results data for these analyses. The investigators within IGAP contributed to the design and implementation of IGAP and/or provided data but did not participate in analysis or writing of this report. IGAP was made possible by the generous participation of the control subjects, the patients, and their families. The i-Select chips were funded by the French National Foundation on Alzheimer's disease and related disorders. EADI was supported by the LABEX (laboratory of excellence program investment for the future) DISTALZ grant, Inserm, Institut Pasteur de Lille, Université de Lille 2 and the Lille University Hospital. GERAD was supported by the Medical Research Council (Grant $n^{\circ}$ 503480), Alzheimer's Research UK (Grant $n^{\circ}$ 503176), the Wellcome Trust (Grant $n^{\circ} 082604 / 2 / 07 / Z$ ) and German Federal Ministry of Education and Research (BMBF): Competence Network Dementia (CND) grant $n^{\circ}$ 01GI0102, 01GI0711, 01GI0420. CHARGE was partly supported by the NIH/NIA grant R01 AG033193 and the NIA AG081220 and AGES contract N01-AG-12100, the NHLBI grant R01 HL105756, the Icelandic Heart Association, and the Erasmus Medical Centre and Erasmus University. ADGC was supported by the NIH/NIA grants: U01 AG032984, U24 AG021886, U01 AG016976, and the Alzheimer's Association grant ADGC-10-196728.

\section{Appendix A. Supplementary data}

Supplementary data to this article can be found online at https://doi. org/10.1016/j.nicl.2020.102527. 


\section{References}

Albert, M.S., DeKosky, S.T., Dickson, D., Dubois, B., Feldman, H.H., Fox, N.C., Gamst, A., Holtzman, D.M., Jagust, W.J., Petersen, R.C., Snyder, P.J., Carrillo, M.C., Thies, B. Phelps, C.H., 2011. The diagnosis of mild cognitive impairment due to Alzheimer's disease: recommendations from the National Institute on Aging-Alzheimer's Association workgroups on diagnostic guidelines for Alzheimer's disease. Alzheimers Dement 7, 270-279.

Barker, M.S., Young, B., Robinson, G.A., 2017. Cohesive and coherent connected speech deficits in mild stroke. Brain Lang. 168, 23-36.

Baxter, D.M., Warrington, E.K., 1994. Measuring dysgraphia: a graded-difficulty spelling test. Behav. Neurol. 7, 107-116.

Benyamin, B., Ferreira, M.A., Willemsen, G., Gordon, S., Middelberg, R.P., McEvoy, B.P., Hottenga, J.J., Henders, A.K., Campbell, M.J., Wallace, L., Frazer, I.H., Heath, A.C., de Geus, E.J., Nyholt, D.R., Visscher, P.M., Penninx, B.W., Boomsma, D.I., Martin, N. G., Montgomery, G.W., Whitfield, J.B., 2009. Common variants in TMPRSS6 are associated with iron status and erythrocyte volume. Nat. Genet. 41, 1173-1175.

Bertoux, M., Volle, E., de Souza, L.C., Funkiewiez, A., Dubois, B., Habert, M.O., 2014. Neural correlates of the mini-SEA (Social cognition and Emotional Assessment) in behavioral variant frontotemporal dementia. Brain Imaging Behav. 8, 1-6.

Borne, L., Rivière, D., Mancip, M., Mangin, J.F., 2020. Automatic labeling of cortical sulci using patch- or CNN-based segmentation techniques combined with bottom-up geometric constraints. Med. Image Anal. 62, 101651.

Burgess, P., Shallice, T., 1997. The Hayling and Brixton Tests. Thames Valley Company, Edmonds, United Kingdom.

Burnham, S.C., Laws, S.M., Budgeon, C.A., Doré, V., Porter, T., Bourgeat, P., Buckley, R. F., Murray, K., Ellis, K.A., Turlach, B.A., Salvado, O., Ames, D., Martins, R.N., Rentz, D., Masters, C.L., Rowe, C.C., Villemagne, V.L., 2020. Impact of APOE- 44 carriage on the onset and rates of neocortical A $\beta$-amyloid deposition. Neurobiol. Aging 95, 46-55.

Chiang, G.C., Insel, P.S., Tosun, D., Schuff, N., Truran-Sacrey, D., Raptentsetsang, S.T., Jack Jr., C.R., Aisen, P.S., Petersen, R.C., Weiner, M.W., Alzheimer's Disease Neuroimaging, I., 2010. Hippocampal atrophy rates and CSF biomarkers in elderly APOE2 normal subjects. Neurology 75, 1976-1981.

Chiti, F., Dobson, C.M., 2006. Protein misfolding, functional amyloid, and human disease. Annu. Rev. Biochem. 75, 333-366.

Corbett, A., Owen, A., Hampshire, A., Grahn, J., Stenton, R., Dajani, S., Burns, A., Howard, R., Williams, N., Williams, G., Ballard, C., 2015. The effect of an online cognitive training package in healthy older adults: an online randomized controlled trial. J Am Med Dir Assoc 16, 990-997.

Cuellar-Partida, G., Springelkamp, H., Lucas, S.E., Yazar, S., Hewitt, A.W., Iglesias, A.I., Montgomery, G.W., Martin, N.G., Pennell, C.E., van Leeuwen, E.M., Verhoeven, V.J., Hofman, A., Uitterlinden, A.G., Ramdas, W.D., Wolfs, R.C., Vingerling, J.R., Brown, M.A., Mills, R.A., Craig, J.E., Klaver, C.C., van Duijn, C.M., Burdon, K.P., MacGregor, S., Mackey, D.A., 2015. WNT10A exonic variant increases the risk of keratoconus by decreasing corneal thickness. Hum. Mol. Genet. 24, 5060-5068.

Desikan, R.S., Fan, C.C., Wang, Y., Schork, A.J., Cabral, H.J., Cupples, L.A., Thompson, W.K., Besser, L., Kukull, W.A., Holland, D., Chen, C.H., Brewer, J.B., Karow, D.S., Kauppi, K., Witoelar, A., Karch, C.M., Bonham, L.W., Yokoyama, J.S., Rosen, H.J., Miller, B.L., Dillon, W.P., Wilson, D.M., Hess, C.P., Pericak-Vance, M., Haines, J.L., Farrer, L.A., Mayeux, R., Hardy, J., Goate, A.M., Hyman, B.T., Schellenberg, G.D., McEvoy, L.K., Andreassen, O.A., Dale, A.M., 2017. Genetic assessment of age-associated Alzheimer disease risk: Development and validation of a polygenic hazard score. PLoS Med. 14, e1002258.

Dubois, B., Hampel, H., Feldman, H.H., Scheltens, P., Aisen, P., Andrieu, S., Bakardjian, H., Benali, H., Bertram, L., Blennow, K., Broich, K., Cavedo, E., Crutch, S., Dartigues, J.F., Duyckaerts, C., Epelbaum, S., Frisoni, G.B., Gauthier, S., Genthon, R., Gouw, A.A., Habert, M.O., Holtzman, D.M., Kivipelto, M., Lista, S., Molinuevo, J.L., O'Bryant, S.E., Rabinovici, G.D., Rowe, C., Salloway, S., Schneider, L.S., Sperling, R., Teichmann, M., Carrillo, M.C., Cummings, J., Jack Jr., C.R., 2016. Preclinical Alzheimer's disease: Definition, natural history, and diagnostic criteria. Alzheimers Dement 12, 292-323.

Ellis, K.A., Bush, A.I., Darby, D., De Fazio, D., Foster, J., Hudson, P., Lautenschlager, N. T., Lenzo, N., Martins, R.N., Maruff, P., Masters, C., Milner, A., Pike, K., Rowe, C., Savage, G., Szoeke, C., Taddei, K., Villemagne, V., Woodward, M., Ames, D., 2009. The Australian Imaging, Biomarkers and Lifestyle (AIBL) study of aging: methodology and baseline characteristics of 1112 individuals recruited for longitudinal study of Alzheimer's disease. Int. Psychogeriatr. 21, 672-687.

Escott-Price, V., Sims, R., Bannister, C., Harold, D., Vronskaya, M., Majounie, E. Badarinarayan, N., Morgan, K., Passmore, P., Holmes, C., Powell, J., Brayne, C. Gill, M., Mead, S., Goate, A., Cruchaga, C., Lambert, J.C., van Duijn, C., Maier, W., Ramirez, A., Holmans, P., Jones, L., Hardy, J., Seshadri, S., Schellenberg, G.D., Amouyel, P., Williams, J., 2015. Common polygenic variation enhances risk prediction for Alzheimer's disease. Brain 138, 3673-3684.

Fodero-Tavoletti, M.T., Brockschnieder, D., Villemagne, V.L., Martin, L., Connor, A.R., Thiele, A., Berndt, M., McLean, C.A., Krause, S., Rowe, C.C., Masters, C.L. Dinkelborg, L., Dyrks, T., Cappai, R., 2012. In vitro characterization of [18F] florbetaben, an Abeta imaging radiotracer. Nucl. Med. Biol. 39, 1042-1048.

Foley, S.F., Tansey, K.E., Caseras, X., Lancaster, T., Bracht, T., Parker, G., Hall, J., Williams, J., Linden, D.E. 2017. Multimodal brain imaging reveals structural differences in Alzheimer's disease polygenic risk carriers: a study in healthy young adults. Biol. Psychiatry 81, 154-161.

Ganguli, M., Dodge, H.H., Shen, C., DeKosky, S.T., 2004. Mild cognitive impairment, amnestic type: an epidemiologic study. Neurology 63, 115-121.

Gauthier, S., Reisberg, B., Zaudig, M., Petersen, R.C., Ritchie, K., Broich, K., Belleville, S., Brodaty, H., Bennett, D., Chertkow, H., Cummings, J.L., de Leon, M., Feldman, H.,
Ganguli, M., Hampel, H., Scheltens, P., Tierney, M.C., Whitehouse, P., Winblad, B., International Psychogeriatric Association Expert Conference on mild cognitive, i., 2006. Mild cognitive impairment. Lancet 367, 1262-1270.

Good, C.D., Johnsrude, I.S., Ashburner, J., Henson, R.N., Friston, K.J., Frackowiak, R.S., 2001. A voxel-based morphometric study of ageing in 465 normal adult human brains. Neuroimage 14, 21-36.

Harold, D., Abraham, R., Hollingworth, P., Sims, R., Gerrish, A., Hamshere, M.L., Pahwa, J.S., Moskvina, V., Dowzell, K., Williams, A., Jones, N., Thomas, C., Stretton, A., Morgan, A.R., Lovestone, S., Powell, J., Proitsi, P., Lupton, M.K., Brayne, C., Rubinsztein, D.C., Gill, M., Lawlor, B., Lynch, A., Morgan, K., Brown, K. S., Passmore, P.A., Craig, D., McGuinness, B., Todd, S., Holmes, C., Mann, D., Smith, A.D., Love, S., Kehoe, P.G., Hardy, J., Mead, S., Fox, N., Rossor, M., Collinge, J., Maier, W., Jessen, F., Schurmann, B., van den Bussche, H., Heuser, I., Kornhuber, J., Wiltfang, J., Dichgans, M., Frolich, L., Hampel, H., Hull, M., Rujescu, D., Goate, A.M., Kauwe, J.S., Cruchaga, C., Nowotny, P., Morris, J.C., Mayo, K., Sleegers, K., Bettens, K., Engelborghs, S., De Deyn, P.P., Van Broeckhoven, C., Livingston, G., Bass, N.J., Gurling, H., McQuillin, A., Gwilliam, R., Deloukas, P., Al-Chalabi, A., Shaw, C.E., Tsolaki, M., Singleton, A.B., Guerreiro, R., Muhleisen, T.W., Nothen, M.M., Moebus, S., Jockel, K.H., Klopp, N., Wichmann, H. E., Carrasquillo, M.M., Pankratz, V.S., Younkin, S.G., Holmans, P.A., O’Donovan, M., Owen, M.J., Williams, J., 2009. Genome-wide association study identifies variants at CLU and PICALM associated with Alzheimer's disease. Nat. Genet. 41, 1088-1093.

Harris, P.A., Taylor, R., Thielke, R., Payne, J., Gonzalez, N., Conde, J.G., 2009. Research electronic data capture (REDCap)-a metadata-driven methodology and workflow process for providing translational research informatics support. J. Biomed. Inform. $42,377-381$.

Harrison, T.M., Mahmood, Z., Lau, E.P., Karacozoff, A.M., Burggren, A.C., Small, G.W., Bookheimer, S.Y., 2016. An Alzheimer's Disease Genetic Risk Score Predicts longitudinal thinning of hippocampal complex subregions in healthy older adults. eNeuro 3. ENEURO.0098-0016.2016.

Heath, A.C., Whitfield, J.B., Martin, N.G., Pergadia, M.L., Goate, A.M., Lind, P.A., McEvoy, B.P., Schrage, A.J., Grant, J.D., Chou, Y.L., Zhu, R., Henders, A.K., Medland, S.E., Gordon, S.D., Nelson, E.C., Agrawal, A., Nyholt, D.R., Bucholz, K.K., Madden, P.A., Montgomery, G.W., 2011. A quantitative-trait genome-wide association study of alcoholism risk in the community: findings and implications. Biol. Psychiatry 70, 513-518.

Hollingworth, P., Harold, D., Sims, R., Gerrish, A., Lambert, J.C., Carrasquillo, M.M., Abraham, R., Hamshere, M.L., Pahwa, J.S., Moskvina, V., Dowzell, K., Jones, N., Stretton, A., Thomas, C., Richards, A., Ivanov, D., Widdowson, C., Chapman, J., Lovestone, S., Powell, J., Proitsi, P., Lupton, M.K., Brayne, C., Rubinsztein, D.C., Gill, M., Lawlor, B., Lynch, A., Brown, K.S., Passmore, P.A., Craig, D., McGuinness, B., Todd, S., Holmes, C., Mann, D., Smith, A.D., Beaumont, H., Warden, D., Wilcock, G., Love, S., Kehoe, P.G., Hooper, N.M., Vardy, E.R., Hardy, J., Mead, S., Fox, N.C., Rossor, M., Collinge, J., Maier, W., Jessen, F., Ruther, E., Schurmann, B., Heun, R., Kolsch, H., van den Bussche, H., Heuser, I., Kornhuber, J., Wiltfang, J., Dichgans, M., Frolich, L., Hampel, H., Gallacher, J., Hull, M., Rujescu, D., Giegling, I., Goate, A.M., Kauwe, J.S., Cruchaga, C., Nowotny, P., Morris, J.C., Mayo, K., Sleegers, K., Bettens, K., Engelborghs, S., De Deyn, P.P., Van Broeckhoven, C., Livingston, G., Bass, N.J., Gurling, H., McQuillin, A., Gwilliam, R., Deloukas, P., Al-Chalabi, A., Shaw, C.E., Tsolaki, M., Singleton, A.B., Guerreiro, R., Muhleisen, T.W., Nothen, M.M., Moebus, S., Jockel, K.H., Klopp, N., Wichmann, H. E., Pankratz, V.S., Sando, S.B., Aasly, J.O., Barcikowska, M., Wszolek, Z.K., Dickson, D.W., Graff-Radford, N.R., Petersen, R.C., van Duijn, C.M., Breteler, M.M., Ikram, M.A., DeStefano, A.L., Fitzpatrick, A.L., Lopez, O., Launer, L.J., Seshadri, S., Berr, C., Campion, D., Epelbaum, J., Dartigues, J.F., Tzourio, C., Alperovitch, A., Lathrop, M., Feulner, T.M., Friedrich, P., Riehle, C., Krawczak, M., Schreiber, S., Mayhaus, M., Nicolhaus, S., Wagenpfeil, S., Steinberg, S., Stefansson, H., Stefansson, K., Snaedal, J., Bjornsson, S., Jonsson, P.V., Chouraki, V., GenierBoley, B., Hiltunen, M., Soininen, H., Combarros, O., Zelenika, D., Delepine, M., Bullido, M.J., Pasquier, F., Mateo, I., Frank-Garcia, A., Porcellini, E., Hanon, O., Coto, E., Alvarez, V., Bosco, P., Siciliano, G., Mancuso, M., Panza, F., Solfrizzi, V., Nacmias, B., Sorbi, S., Bossu, P., Piccardi, P., Arosio, B., Annoni, G., Seripa, D., Pilotto, A., Scarpini, E., Galimberti, D., Brice, A., Hannequin, D., Licastro, F., Jones, L., Holmans, P.A., Jonsson, T., Riemenschneider, M., Morgan, K., Younkin, S. G., Owen, M.J., O'Donovan, M., Amouyel, P., Williams, J., 2011. Common variants at ABCA7, MS4A6A/MS4A4E, EPHA1, CD33 and CD2AP are associated with Alzheimer's disease. Nat. Genet. 43, 429-435.

Iturria-Medina, Y., Carbonell, F.M., Sotero, R.C., Chouinard-Decorte, F., Evans, A.C., 2017. Multifactorial causal model of brain (dis)organization and therapeutic intervention: application to Alzheimer's disease. Neuroimage 152, 60-77.

Ivnik, R.J., Malec, J.F., Tangalos, E.G., Petersen, R.C., Kokmen, E., Kurland, L.T., 1990. The Auditory-Verbal Learning Test (AVLT): norms for ages 55 years and older. Psychol. Assess.: J. Consul. Clin. Psychol. 2, 304-312.

Jackson, M., Warrington, E.K., 1986. Arithmetic skills in patients with unilateral cerebral lesions. Cortex 22, 611-620.

Kessels, R.P., Montagne, B., Hendriks, A.W., Perrett, D.I., de Haan, E.H., 2014. Assessment of perception of morphed facial expressions using the Emotion Recognition Task: normative data from healthy participants aged 8-75. J. Neuropsychol. 8, 75-93.

Kivimaki, M., Luukkonen, R., Batty, G.D., Ferrie, J.E., Pentti, J., Nyberg, S.T., Shipley, M. J., Alfredsson, L., Fransson, E.I., Goldberg, M., Knutsson, A., Koskenvuo, M., Kuosma, E., Nordin, M., Suominen, S.B., Theorell, T., Vuoksimaa, E., Westerholm, P., Westerlund, H., Zins, M., Kivipelto, M., Vahtera, J., Kaprio, J., Singh-Manoux, A., Jokela, M., 2018. Body mass index and risk of dementia: Analysis of individual-level data from 1.3 million individuals. Alzheimers Dement 14, 601-609. 
Konijnenberg, E., Carter, S.F., Ten Kate, M., den Braber, A., Tomassen, J., Amadi, C., Wesselman, L., Nguyen, H.T., van de Kreeke, J.A., Yaqub, M., Demuru, M., Mulder, S.D., Hillebrand, A., Bouwman, F.H., Teunissen, C.E., Serne, E.H., Moll, A. C., Verbraak, F.D., Hinz, R., Pendleton, N., Lammertsma, A.A., van Berckel, B.N.M., Barkhof, F., Boomsma, D.I., Scheltens, P., Herholz, K., Visser, P.J., 2018. The EMIF$\mathrm{AD}$ PreclinAD study: study design and baseline cohort overview. Alzheimers Res. Ther. 10, 75 .

Kunkle, B.W., Grenier-Boley, B., Sims, R., Bis, J.C., Naj, A.C., Boland, A., Vronskaya, M., van der Lee, S.J., Amlie-Wolf, A., Bellenguez, C., Frizatti, A., Chouraki, V., Schmidt, H., Hakonarson, H., Munger, R., Schmidt, R., Farrer, L.A., Van Broeckhoven, C., O'Donovan, M.C., Destefano, A.L., Jones, L., Haines, J.L., Deleuze, J.-F., Owen, M.J., Gudnason, V., Mayeux, R.P., Escott-Price, V., Psaty, B.M., Ruiz, A., Ramirez, A., Wang, L.-S., van Duijn, C.M., Holmans, P.A., Seshadri, S., Williams, J., Amouyel, P., Schellenberg, G.D., Lambert, J.-C., Pericak-Vance, M.A., 2019. Meta-analysis of genetic association with diagnosed Alzheimer's disease identifies novel risk loci and implicates Abeta, Tau, immunity and lipid processing. Nat. Genet. 51, 414-430.

Lam, B., Masellis, M., Freedman, M., Stuss, D.T., Black, S.E., 2013. Clinical, imaging, and pathological heterogeneity of the Alzheimer's disease syndrome. Alzheimers Res. Ther. 5, 1 .

Lambert, J.C., Heath, S., Even, G., Campion, D., Sleegers, K., Hiltunen, M., Combarros, O., Zelenika, D., Bullido, M.J., Tavernier, B., Letenneur, L., Bettens, K., Berr, C., Pasquier, F., Fievet, N., Barberger-Gateau, P., Engelborghs, S., De, D.P., Mateo, I., Franck, A., Helisalmi, S., Porcellini, E., Hanon, O., de Pancorbo, M.M., Lendon, C., Dufouil, C., Jaillard, C., Leveillard, T., Alvarez, V., Bosco, P., Mancuso, M., Panza, F., Nacmias, B., Bossu, P., Piccardi, P., Annoni, G., Seripa, D. Galimberti, D., Hannequin, D., Licastro, F., Soininen, H., Ritchie, K., Blanche, H., Dartigues, J.F., Tzourio, C., Gut, I., Van, B.C., Alperovitch, A., Lathrop, M., Amouyel, P., 2009. Genome-wide association study identifies variants at CLU and CR1 associated with Alzheimer's disease. Nat. Genet. 41, 1094-1099.

Lambert, J.C., Ibrahim-Verbaas, C.A., Harold, D., Naj, A.C., Sims, R., Bellenguez, C., Jun, G., Destefano, A.L., Bis, J.C., Beecham, G.W., Grenier-Boley, B., Russo, G., Thornton-Wells, T.A., Jones, N., Smith, A.V., Chouraki, V., Thomas, C., Ikram, M.A., Zelenika, D., Vardarajan, B.N., Kamatani, Y., Lin, C.F., Gerrish, A., Schmidt, H., Kunkle, B., Dunstan, M.L., Ruiz, A., Bihoreau, M.T., Choi, S.H., Reitz, C., Pasquier, F., Hollingworth, P., Ramirez, A., Hanon, O., Fitzpatrick, A.L., Buxbaum, J.D., Campion, D., Crane, P.K., Baldwin, C., Becker, T., Gudnason, V., Cruchaga, C. Craig, D., Amin, N., Berr, C., Lopez, O.L., De Jager, P.L., Deramecourt, V., Johnston, J.A., Evans, D., Lovestone, S., Letenneur, L., Moron, F.J., Rubinsztein, D. C., Eiriksdottir, G., Sleegers, K., Goate, A.M., Fievet, N., Huentelman, M.J., Gill, M., Brown, K., Kamboh, M.I., Keller, L., Barberger-Gateau, P., McGuinness, B., Larson, E. B., Green, R., Myers, A.J., Dufouil, C., Todd, S., Wallon, D., Love, S., Rogaeva, E., Gallacher, J., St George-Hyslop, P., Clarimon, J., Lleo, A., Bayer, A., Tsuang, D.W., Yu, L., Tsolaki, M., Bossu, P., Spalletta, G., Proitsi, P., Collinge, J., Sorbi, S., SanchezGarcia, F., Fox, N.C., Hardy, J., Naranjo, M.C., Bosco, P., Clarke, R., Brayne, C., Galimberti, D., Mancuso, M., Matthews, F., European Alzheimer's Disease, I., Genetic, Environmental Risk in Alzheimer's, D., Alzheimer's Disease Genetic, C. Cohorts for, H., Aging Research in Genomic, E., Moebus, S., Mecocci, P., Del Zompo, M., Maier, W., Hampel, H., Pilotto, A., Bullido, M., Panza, F., Caffarra, P., Nacmias, B., Gilbert, J.R., Mayhaus, M., Lannfelt, L., Hakonarson, H., Pichler, S., Carrasquillo, M.M., Ingelsson, M., Beekly, D., Alvarez, V., Zou, F., Valladares, O., Younkin, S.G., Coto, E., Hamilton-Nelson, K.L., Gu, W., Razquin, C., Pastor, P., Mateo, I., Owen, M.J., Faber, K.M., Jonsson, P.V., Combarros, O., O’Donovan, M.C., Cantwell, L.B., Soininen, H., Blacker, D., Mead, S., Mosley Jr., T.H., Bennett, D.A., Harris, T.B., Fratiglioni, L., Holmes, C., de Bruijn, R.F., Passmore, P., Montine, T.J., Bettens, K., Rotter, J.I., Brice, A., Morgan, K., Foroud, T.M., Kukull, W.A., Hannequin, D., Powell, J.F., Nalls, M.A., Ritchie, K., Lunetta, K.L., Kauwe, J.S., Boerwinkle, E., Riemenschneider, M., Boada, M., Hiltunen, M., Martin, E.R., Schmidt, R., Rujescu, D., Wang, L.S., Dartigues, J.F., Mayeux, R., Tzourio, C., Hofman, A., Nothen, M.M., Graff, C., Psaty, B.M., Jones, L., Haines, J.L., Holmans, P. A., Lathrop, M., Pericak-Vance, M.A., Launer, L.J., Farrer, L.A., van Duijn, C.M., Van Broeckhoven, C., Moskvina, V., Seshadri, S., Williams, J., Schellenberg, G.D., Amouyel, P., 2013. Meta-analysis of 74,046 individuals identifies 11 new susceptibility loci for Alzheimer's disease. Nat. Genet. 45, 1452-1458.

LaMonica, H.M., English, A., Hickie, I.B., Ip, J., Ireland, C., West, S., Shaw, T., Mowszowski, L., Glozier, N., Duffy, S., Gibson, A.A., Naismith, S.L., 2017. Examining internet and ehealth practices and preferences: survey study of Australian older adults with subjective memory complaints, mild cognitive impairment, or dementia. J. Med. Internet Res., e358

Lim, Y.Y., Villemagne, V.L., Pietrzak, R.H., Ames, D., Ellis, K.A., Harrington, K., Snyder, P.J., Martins, R.N., Masters, C.L., Rowe, C.C., Maruff, P., Australian Imaging, B., Lifestyle Research, G., 2015. APOE epsilon4 moderates amyloid-related memory decline in preclinical Alzheimer's disease. Neurobiol. Aging 36, 1239-1244.

Livingston, G., Huntley, J., Sommerlad, A., Ames, D., Ballard, C., Banerjee, S., Brayne, C., Burns, A., Cohen-Mansfield, J., Cooper, C., Costafreda, S.G., Dias, A., Fox, N., Gitlin, L.N., Howard, R., Kales, H.C., Kivimaki, M., Larson, E.B., Ogunniyi, A., Orgeta, V., Ritchie, K., Rockwood, K., Sampson, E.L., Samus, Q., Schneider, L.S., Selbaek, G., Teri, L., Mukadam, N., 2020. Dementia prevention, intervention, and care: 2020 report of the Lancet Commission. Lancet 396, 413-446.

Loughrey, D.G., Kelly, M.E., Kelley, G.A., Brennan, S., Lawlor, B.A., 2018. Association of age-related hearing loss with cognitive function, cognitive impairment, and dementia: a systematic review and meta-analysis. JAMA Otolaryngol. Head Neck Surg. 144, 115-126.

Lupton, M.K., Benyamin, B., Proitsi, P., Nyholt, D.R., Ferreira, M.A., Montgomery, G.W., Heath, A.C., Madden, P.A., Medland, S.E., Gordon, S.D., Consortium, G., Alzheimer's Disease Neuroimaging, I., Lovestone, S., Tsolaki, M., Kloszewska, I., Soininen, H.,
Mecocci, P., Vellas, B., Powell, J.F., Bush, A.I., Wright, M.J., Martin, N.G., Whitfield, J.B., 2017. No genetic overlap between circulating iron levels and Alzheimer's Disease. J. Alzheimers Dis. 59, 85-99.

Lupton, M.K., Medland, S.E., Gordon, S.D., Goncalves, T., MacGregor, S., Mackey, D.A., Young, T.L., Duffy, D.L., Visscher, P.M., Wray, N.R., Nyholt, D.R., Bain, L., Ferreira, M.A., Henders, A.K., Wallace, L., Montgomery, G.W., Wright, M.J., Martin, N.G., 2018. Accuracy of Inferred APOE Genotypes for a Range of Genotyping Arrays and Imputation Reference Panels. J. Alzheimers Dis. 64, 49-54.

Lupton, M.K., Strike, L., Hansell, N.K., Wen, W., Mather, K.A., Armstrong, N.J., Thalamuthu, A., McMahon, K.L., de Zubicaray, G.I., Assareh, A.A., Simmons, A., Proitsi, P., Powell, J.F., Montgomery, G.W., Hibar, D.P., Westman, E., Tsolaki, M., Kloszewska, I., Soininen, H., Mecocci, P., Velas, B., Lovestone, S., Brodaty, H., Ames, D., Trollor, J.N., Martin, N.G., Thompson, P.M., Sachdev, P.S., Wright, M.J., 2016. The effect of increased genetic risk for Alzheimer's disease on hippocampal and amygdala volume. Neurobiol. Aging 40, 68-77.

Marcus, D.S., Olsen, T.R., Ramaratnam, M., Buckner, R.L., 2007. The Extensible Neuroimaging Archive Toolkit: an informatics platform for managing, exploring, and sharing neuroimaging data. Neuroinformatics 5, 11-34.

Marques, J.P., Kober, T., Krueger, G., van der Zwaag, W., Van de Moortele, P.F., Gruetter, R., 2010. MP2RAGE, a self bias-field corrected sequence for improved segmentation and T1-mapping at high field. Neuroimage 49, 1271-1281.

McCarthy, S., Das, S., Kretzschmar, W., Delaneau, O., Wood, A.R., Teumer, A., Kang, H. M., Fuchsberger, C., Danecek, P., Sharp, K., Luo, Y., Sidore, C., Kwong, A., Timpson, N., Koskinen, S., Vrieze, S., Scott, L.J., Zhang, H., Mahajan, A., Veldink, J., Peters, U., Pato, C., van Duijn, C.M., Gillies, C.E., Gandin, I., Mezzavilla, M., Gilly, A., Cocca, M., Traglia, M., Angius, A., Barrett, J.C., Boomsma, D., Branham, K., Breen, G., Brummett, C.M., Busonero, F., Campbell, H., Chan, A., Chen, S., Chew, E., Collins, F.S., Corbin, L.J., Smith, G.D., Dedoussis, G., Dorr, M., Farmaki, A.E., Ferrucci, L., Forer, L., Fraser, R.M., Gabriel, S., Levy, S., Groop, L., Harrison, T., Hattersley, A., Holmen, O.L., Hveem, K., Kretzler, M., Lee, J.C., McGue, M. Meitinger, T., Melzer, D., Min, J.L., Mohlke, K.L., Vincent, J.B., Nauck, M., Nickerson, D., Palotie, A., Pato, M., Pirastu, N., McInnis, M., Richards, J.B., Sala, C., Salomaa, V., Schlessinger, D., Schoenherr, S., Slagboom, P.E., Small, K., Spector, T., Stambolian, D., Tuke, M., Tuomilehto, J., Van den Berg, L.H., Van Rheenen, W., Volker, U., Wijmenga, C., Toniolo, D., Zeggini, E., Gasparini, P., Sampson, M.G., Wilson, J.F., Frayling, T., de Bakker, P.I., Swertz, M.A., McCarroll, S., Kooperberg, C., Dekker, A., Altshuler, D., Willer, C., Iacono, W., Ripatti, S., Soranzo, N., Walter, K., Swaroop, A., Cucca, F., Anderson, C.A., Myers, R.M., Boehnke, M., McCarthy, M.I., Durbin, R., 2016. A reference panel of 64,976 haplotypes for genotype imputation. Nat. Genet. 48, 1279-1283.

McDonald, S., Flanagan, S., Honan, C., 2017. The Awareness of Social Inference TEST Short (TASIT-S) Manual.

McGrath, E.R., Beiser, A.S., DeCarli, C., Plourde, K.L., Vasan, R.S., Greenberg, S.M., Seshadri, S., 2017. Blood pressure from mid- to late life and risk of incident dementia. Neurology 89, 2447-2454.

McKhann, G.M., Knopman, D.S., Chertkow, H., Hyman, B.T., Jack Jr., C.R., Kawas, C.H., Klunk, W.E., Koroshetz, W.J., Manly, J.J., Mayeux, R., Mohs, R.C., Morris, J.C., Rossor, M.N., Scheltens, P., Carrillo, M.C., Thies, B., Weintraub, S., Phelps, C.H., 2011. The diagnosis of dementia due to Alzheimer's disease: recommendations from the National Institute on Aging-Alzheimer's Association workgroups on diagnostic guidelines for Alzheimer's disease. Alzheimers Dement 7, 263-269.

Medland, S.E., Nyholt, D.R., Painter, J.N., McEvoy, B.P., McRae, A.F., Zhu, G., Gordon, S. D., Ferreira, M.A., Wright, M.J., Henders, A.K., Campbell, M.J., Duffy, D.L., Hansell, N.K., Macgregor, S., Slutske, W.S., Heath, A.C., Montgomery, G.W., Martin, N.G., 2009. Common variants in the trichohyalin gene are associated with straight hair in Europeans. Am. J. Hum. Genet. 85, 750-755.

Mielke, M.M., Machulda, M.M., Hagen, C.E., Edwards, K.K., Roberts, R.O., Pankratz, V. S., Knopman, D.S., Jack Jr., C.R., Petersen, R.C., 2015. Performance of the CogState computerized battery in the Mayo Clinic Study on Aging. Alzheimers Dement 11, 1367-1376.

Morris, J.C., 2005. Early-stage and preclinical Alzheimer disease. Alzheimer Dis. Assoc. Disord. 19, 163-165.

Mueller, S.G., Weiner, M.W., Thal, L.J., Petersen, R.C., Jack, C.R., Jagust, W., Trojanowski, J.Q., Toga, A.W., Beckett, L., 2005. Ways toward an early diagnosis in Alzheimer's disease: the Alzheimer's Disease Neuroimaging Initiative (ADNI). Alzheimers Dement 1, 55-66.

Mugler 3rd, J.P., Brookeman, J.R., 1990. Three-dimensional magnetization-prepared rapid gradient-echo imaging (3D MP RAGE). Magn. Reson. Med. 15, 152-157.

Naj, A.C., Jun, G., Beecham, G.W., Wang, L.S., Vardarajan, B.N., Buros, J., Gallins, P.J., Buxbaum, J.D., Jarvik, G.P., Crane, P.K., Larson, E.B., Bird, T.D., Boeve, B.F., GraffRadford, N.R., De Jager, P.L., Evans, D., Schneider, J.A., Carrasquillo, M.M., ErtekinTaner, N., Younkin, S.G., Cruchaga, C., Kauwe, J.S., Nowotny, P., Kramer, P., Hardy, J., Huentelman, M.J., Myers, A.J., Barmada, M.M., Demirci, F.Y., Baldwin, C. T., Green, R.C., Rogaeva, E., St George-Hyslop, P., Arnold, S.E., Barber, R., Beach, T., Bigio, E.H., Bowen, J.D., Boxer, A., Burke, J.R., Cairns, N.J., Carlson, C.S., Carney, R. M., Carroll, S.L., Chui, H.C., Clark, D.G., Corneveaux, J., Cotman, C.W., Cummings, J.L., DeCarli, C., DeKosky, S.T., Diaz-Arrastia, R., Dick, M., Dickson, D. W., Ellis, W.G., Faber, K.M., Fallon, K.B., Farlow, M.R., Ferris, S., Frosch, M.P., Galasko, D.R., Ganguli, M., Gearing, M., Geschwind, D.H., Ghetti, B., Gilbert, J.R., Gilman, S., Giordani, B., Glass, J.D., Growdon, J.H., Hamilton, R.L., Harrell, L.E., Head, E., Honig, L.S., Hulette, C.M., Hyman, B.T., Jicha, G.A., Jin, L.W., Johnson, N., Karlawish, J., Karydas, A., Kaye, J.A., Kim, R., Koo, E.H., Kowall, N.W., Lah, J.J., Levey, A.I., Lieberman, A.P., Lopez, O.L., Mack, W.J., Marson, D.C., Martiniuk, F., Mash, D.C., Masliah, E., McCormick, W.C., McCurry, S.M., McDavid, A.N., McKee, A. C., Mesulam, M., Miller, B.L., Miller, C.A., Miller, J.W., Parisi, J.E., Perl, D.P., Peskind, E., Petersen, R.C., Poon, W.W., Quinn, J.F., Rajbhandary, R.A., Raskind, M., 
Reisberg, B., Ringman, J.M., Roberson, E.D., Rosenberg, R.N., Sano, M., Schneider, L.S., Seeley, W., Shelanski, M.L., Slifer, M.A., Smith, C.D., Sonnen, J.A., Spina, S., Stern, R.A., Tanzi, R.E., Trojanowski, J.Q., Troncoso, J.C., Van Deerlin, V. M., Vinters, H.V., Vonsattel, J.P., Weintraub, S., Welsh-Bohmer, K.A., Williamson, J., Woltjer, R.L., Cantwell, L.B., Dombroski, B.A., Beekly, D., Lunetta, K.L., Martin, E.R., Kamboh, M.I., Saykin, A.J., Reiman, E.M., Bennett, D.A., Morris, J.C., Montine, T.J., Goate, A.M., Blacker, D., Tsuang, D.W., Hakonarson, H., Kukull, W.A., Foroud, T.M., Haines, J.L., Mayeux, R., Pericak-Vance, M.A., Farrer, L.A., Schellenberg, G.D., 2011 Common variants at MS4A4/MS4A6E, CD2AP, CD33 and EPHA1 are associated with late-onset Alzheimer's disease. Nat. Genet. 43, 436-441.

Nelson, H.E., Willison, J., 1991. National adult reading test (NART). Nfer-Nelson, Windsor, UK.

Ning, S., Jorfi, M., 2019. Beyond the sleep-amyloid interactions in Alzheimer's disease pathogenesis. J. Neurophysiol. 122, 1-4.

Okubo, G., Okada, T., Yamamoto, A., Kanagaki, M., Fushimi, Y., Okada, T., Murata, K., Togashi, K., 2016. MP2RAGE for deep gray matter measurement of the brain: a comparative study with MPRAGE. J. Magn. Reson. Imaging 43, 55-62.

Opie, R.S., Ralston, R.A., Walker, K.Z., 2013. Adherence to a Mediterranean-style diet can slow the rate of cognitive decline and decrease the risk of dementia: a systematic review. Nutr. Diet. 70, 206-217.

Ranta, J., Aittokoski, T., Tenhunen, M., Alasaukko-oja, M., 2019. EMFIT QS heart rate and respiration rate validation. Biomed. Phys. Eng. Express 5, 025016.

Ravaglia, G., Forti, P., Maioli, F., Martelli, M., Servadei, L., Brunetti, N., Pantieri, G., Mariani, E., 2006. Conversion of mild cognitive impairment to dementia: predictive role of mild cognitive impairment subtypes and vascular risk factors. Dement. Geriatr. Cogn. Disord. 21, 51-58.

Robertson, I.H., Ward, T., Ridgeway, V., Nimmo-Smith, I., 1994. The Test of Everyday Attention. Thames Valley Test Company, Bury St. Edmunds, UK.

Robinson, G., Shallice, T., Bozzali, M., Cipolotti, L., 2012. The differing roles of the frontal cortex in fluency tests. Brain 135, 2202-2214.

Robinson, G.A., Cipolotti, L., Walker, D.G., Biggs, V., Bozzali, M., Shallice, T., 2015a. Verbal suppression and strategy use: a role for the right lateral prefrontal cortex? Brain 138, 1084-1096.

Robinson, G.A., Spooner, D., Harrison, W.J., 2015b. Frontal dynamic aphasia in progressive supranuclear palsy: Distinguishing between generation and fluent sequencing of novel thoughts. Neuropsychologia 77, 62-75.

Rowe, C.C., Ackerman, U., Browne, W., Mulligan, R., Pike, K.L., O'Keefe, G., TochonDanguy, H., Chan, G., Berlangieri, S.U., Jones, G., Dickinson-Rowe, K.L., Kung, H.P., Zhang, W., Kung, M.P., Skovronsky, D., Dyrks, T., Holl, G., Krause, S., Friebe, M., Lehman, L., Lindemann, S., Dinkelborg, L.M., Masters, C.L., Villemagne, V.L., 2008. Imaging of amyloid beta in Alzheimer's disease with 18F-BAY94-9172, a novel PET tracer: proof of mechanism. Lancet Neurol. 7, 129-135.

Sabia, S., Dugravot, A., Dartigues, J.-F., Abell, J., Elbaz, A., Kivimäki, M., SinghManoux, A., 2017. Physical activity, cognitive decline, and risk of dementia: 28 year follow-up of Whitehall II cohort study. BMJ 357, j2709.

Sabuncu, M.R., Buckner, R.L., Smoller, J.W., Lee, P.H., Fischl, B., Sperling, R.A., 2012. The association between a polygenic Alzheimer score and cortical thickness in clinically normal subjects. Cereb. Cortex 22, 2653-2661.

Sachdev, P.S., Brodaty, H., Reppermund, S., Kochan, N.A., Trollor, J.N., Draper, B., Slavin, M.J., Crawford, J., Kang, K., Broe, G.A., Mather, K.A., Lux, O., 2010. The Sydney Memory and Ageing Study (MAS): methodology and baseline medical and neuropsychiatric characteristics of an elderly epidemiological non-demented cohort of Australians aged 70-90 years. Int. Psychogeriatr. 22, 1248-1264.

Sachdev, P.S., Lammel, A., Trollor, J.N., Lee, T., Wright, M.J., Ames, D., Wen, W., Martin, N.G., Brodaty, H., Schofield, P.R., 2009. A comprehensive neuropsychiatric study of elderly twins: the Older Australian Twins Study. Twin Res. Hum. Genet. 12, 573-582.

Saunders, A.M., Schmader, K., Breitner, J.C., Benson, M.D., Brown, W.T., Goldfarb, L., Goldgaber, D., Manwaring, M.G., Szymanski, M.H., McCown, N., et al., 1993. Apolipoprotein E epsilon 4 allele distributions in late-onset Alzheimer's disease and in other amyloid-forming diseases. Lancet 342, 710-711.
Smith, A., 1973. Symbol Digit Modalities Test. Western Psychological Services, Los Angeles, USA.

Snaith, R.P., Zigmond, A.S., 1994. The Hospital Anxiety and Depression Scale: Manual. GL Assessment London, UK.

Snowdon, D.A., Kemper, S.J., Mortimer, J.A., Greiner, L.H., Wekstein, D.R., Markesbery, W.R., 1996. Linguistic ability in early life and cognitive function and Alzheimer's disease in late life. Findings from the Nun Study. JAMA 275, 528-532. Strittmatter, W.J., Saunders, A.M., Schmechel, D., Pericak-Vance, M., Enghild, J., Salvesen, G.S., Roses, A.D., 1993. Apolipoprotein E: high-avidity binding to betaamyloid and increased frequency of type 4 allele in late-onset familial Alzheimer disease. Proc. Natl. Acad. Sci. U.S.A. 90, 1977-1981.

Sudlow, C., Gallacher, J., Allen, N., Beral, V., Burton, P., Danesh, J., Downey, P., Elliott, P., Green, J., Landray, M., Liu, B., Matthews, P., Ong, G., Pell, J., Silman, A., Young, A., Sprosen, T., Peakman, T., Collins, R., 2015. UK biobank: an open access resource for identifying the causes of a wide range of complex diseases of middle and old age. PLoS Med. 12, e1001779.

Tan, C.H., Fan, C.C., Mormino, E.C., Sugrue, L.P., Broce, I.J., Hess, C.P., Dillion, W.P., Bonham, L.W., Yokoyama, J.S., Karch, C.M., Brewer, J.B., Rabinovici, G.D., Miller, B. L., Schellenberg, G.D., Kauppi, K., Feldman, H.A., Holland, D., McEvoy, L.K., Hyman, B.T., Andreassen, O.A., Dale, A.M., Desikan, R.S., 2017a. Polygenic hazard score: an enrichment marker for Alzheimer's associated amyloid and tau deposition. Acta Neuropathol. 135, 85-93.

Tan, C.H., Hyman, B.T., Tan, J.J.X., Hess, C.P., Dillon, W.P., Schellenberg, G.D., Besser, L.M., Kukull, W.A., Kauppi, K., McEvoy, L.K., Andreassen, O.A., Dale, A.M., Fan, C.C., Desikan, R.S., 2017b. Polygenic hazard scores in preclinical Alzheimer disease. Ann. Neurol. 82, 484-488.

Tang, X., Cai, F., Ding, D.X., Zhang, L.L., Cai, X.Y., Fang, Q., 2018. Magnetic resonance imaging relaxation time in Alzheimer's disease. Brain Res. Bull. 140, 176-189.

Tombaugh, T.N., Kozak, J., Rees, L., 1999. Normative data stratified by age and education for two measures of verbal fluency: FAS and animal naming. Arch. Clin. Neuropsychol. 14, 167-177.

Troyer, A.K., Leach, L., Strauss, E., 2006. Aging and response inhibition: Normative data for the Victoria Stroop Test. Neuropsychol. Dev. Cogn. B Aging Neuropsychol. Cogn. 13, 20-35.

Villemagne, V.L., Burnham, S., Bourgeat, P., Brown, B., Ellis, K.A., Salvado, O., Szoeke, C., Macaulay, S.L., Martins, R., Maruff, P., Ames, D., Rowe, C.C., Masters, C. L., 2013. Amyloid beta deposition, neurodegeneration, and cognitive decline in sporadic Alzheimer's disease: a prospective cohort study. Lancet Neurol. 12, 357-367.

Warrington, E.K., 1996. The Camden Memory Tests. Psychology Press, Howe, UK.

Warrington, E.K., 1997. In: The Graded Naming Test: A restandardisation. Taylor \& Francis, United Kingdom, pp. 143-146.

Warrington, E.K., James, M., 1991. The Visual Object and Space Perception Battery: VOSP. Pearson.

Wechsler, D., 2003. WISC-IV: Administration and scoring manual. Psychological Corporation, San Antonio, Texas.

Wechsler, D., 2011. Wechsler Abbreviated Scale of Intelligence Second Edition (WASI) Manual. The Psychological Corporation, San Antonio, TX.

Weiner, M.W., Nosheny, R., Camacho, M., Truran-Sacrey, D., Mackin, R.S., Flenniken, D., Ulbricht, A., Insel, P., Finley, S., Fockler, J., Veitch, D., 2018. The Brain Health Registry: An internet-based platform for recruitment, assessment, and longitudinal monitoring of participants for neuroscience studies. Alzheimer's Dementia 14, 1063-1076.

Winblad, B., Palmer, K., Kivipelto, M., Jelic, V., Fratiglioni, L., Wahlund, L.O., Nordberg, A., Backman, L., Albert, M., Almkvist, O., Arai, H., Basun, H., Blennow, K., de Leon, M., DeCarli, C., Erkinjuntti, T., Giacobini, E., Graff, C., Hardy, J., Jack, C., Jorm, A., Ritchie, K., van Duijn, C., Visser, P., Petersen, R.C., 2004. Mild cognitive impairment-beyond controversies, towards a consensus: report of the International Working Group on Mild Cognitive Impairment. J. Intern. Med. 256, 240-246.

Xu, W., Tan, C.C., Zou, J.J., Cao, X.P., Tan, L., 2020. Sleep problems and risk of all-cause cognitive decline or dementia: an updated systematic review and meta-analysis. J. Neurol. Neurosurg. Psychiatry 91, 236-244. 


\section{University Library}

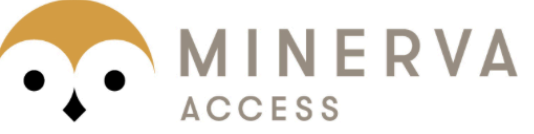

A gateway to Melbourne's research publications

Minerva Access is the Institutional Repository of The University of Melbourne

\section{Author/s:}

Lupton, MK;Robinson, GA;Adam, RJ;Rose, S;Byrne, GJ;Salvado, O;Pachana, NA;Almeida, OP;McAloney, K;Gordon, SD;Raniga, P;Fazlollahi, A;Xia, Y;Ceslis, A;Sonkusare, S;Zhang, Q;Kholghi, M;Karunanithi, M;Mosley, PE;Lv, J;Borne, L;Adsett, J;Garden, N;Fripp, J;Martin, NG;Guo, CC;Breakspear, M

Title:

A prospective cohort study of prodromal Alzheimer's disease: Prospective Imaging Study of Ageing: Genes, Brain and Behaviour (PISA)

Date:

2021-01-01

\section{Citation:}

Lupton, M. K., Robinson, G. A., Adam, R. J., Rose, S., Byrne, G. J., Salvado, O., Pachana, N. A., Almeida, O. P., McAloney, K., Gordon, S. D., Raniga, P., Fazlollahi, A., Xia, Y., Ceslis, A., Sonkusare, S., Zhang, Q., Kholghi, M., Karunanithi, M., Mosley, P. E. ,... Breakspear, M. (2021). A prospective cohort study of prodromal Alzheimer's disease: Prospective Imaging Study of Ageing: Genes, Brain and Behaviour (PISA). NEUROIMAGE-CLINICAL, 29, https:// doi.org/10.1016/j.nicl.2020.102527.

Persistent Link:

http://hdl.handle.net/11343/272989

License:

CC BY 